\title{
Nubia-Eurasia kinematics: an alternative interpretation from Mediterranean and North Atlantic evidence
}

\author{
Enzo Mantovani, Marcello Viti, Daniele Babbucci and Dario Albarello \\ Dipartimento di Scienze della Terra, Università degli Studi di Siena, Italy
}

\begin{abstract}
It is argued that the Plio-Quaternary deformation pattern in the Mediterranean region is compatible with a SSWNNE convergence between Africa (Nubia) and Eurasia and that the significant difference between this kinematics and the one provided by global models (SSE-NNW convergence e.g., the NUVEL-1) may be due to the fact that those models interpret North Atlantic data by adopting an oversimplified two-plate configuration, which cannot account for the occurrence of significant seismotectonic activity inside the presumed Nubia and Eurasia blocks. It is shown that the adoption of a new plate configuration involving the Iberia and Morocco microplates, strongly suggested by geological and seismotectonic evidence, makes it possible to identify a kinematic model compatible within errors with the constraints recognized in the Mediterranean region and with the NUVEL-1 North Atlantic data set. Some considerations are made about why the present-day Nubia-Eurasia kinematic models inferred from geodetic observations are significantly different from long-term models, such as model NUVEL-1 and the one proposed in this work.
\end{abstract}

Key words Nubia-Eurasia kinematics - Mediterranean region - Plio-Quaternary deformation

\section{Introduction}

The huge amount of geological, volcanological and geophysical evidence now available in the Mediterranean region allows a fairly accurate reconstruction of the Neogene time-space distribution of deformation in that area, involving various tectonic processes, such as back-arc basin generation, lithosphere subduction, arc migration and orogenic accretion (e.g., Sengor and Yilmaz, 1981; Dercourt et al., 1986; Finetti, 2005). The features of major observed tectonic events, such as the strain involved, loca-

Mailing address: Dr. Enzo Mantovani, Dipartimento di Scienze della Terra, Università degli Studi di Siena, Via Laterina 8, 53100 Siena, Italy; e-mail: mantovani@unisi.it tion, timing of initiation development and cessation, impose tight constraints on the driving mechanism. In a number of papers (Mantovani et al., 1997, 2001a, 2002, 2006a,b; Babbucci et al., 2004; Viti et al., 2004, 2006; Mantovani, 2005) we argue that the best agreement between predicted and observed Pliocene-Quaternary deformation is obtained when the Mediterranean region is stressed by a NE to NNE-ward motion of Nubia (the stable part of Africa, e.g., Gordon, 1995) and a roughly westward motion of the Anatolian block with respect to Eurasia.

A significantly different Nubia-Eurasia motion trend (NNW to NW ward) is suggested by global kinematic models which have been inferred from North Atlantic evidence (e.g., Minster and Jordan, 1978; Argus et al., 1989; De Mets et al., 1990, 1994), and by the kinematic models inferred from geodetic data (e.g., Sella et al., 2002; Calais et al., 2003; McClusky et al., 2003; Kreemer et al., 2003; Nocquet and Calais, 2004; Prawirodirdjo and Bock, 2004). 
In this work we present some considerations on the possible causes of such differences and propose a new kinematic model which is compatible with Mediterranean evidence and the NUVEL-1 North Atlantic data set. In Section 2, we describe the most significant tectonic features in the Eastern, Central and Western Mediterranean area, which in our opinion may be used as major constraints on the Nubia-Eurasia relative motion. Section 3 points out major seismotectonic evidence in the western part of the study area that suggests the presence of two independent microplates, Iberia and Morocco. In Section 4, we describe the proposed kinematic model and the constraints that have been used. In Section 5, we make some remarks about the uncertainties that might affect the $\mathrm{Nu}$ bia-Eurasia Euler poles inferred from the presently available geodetic data.

\section{Mediterranean constraints on the Plio- Quaternary Nubia-Eurasia kinematics}

The most direct information on the relative motion between two plates is provided by the analysis of the deformation pattern observed at their boundary zone, that in the case of Nubia and Eurasia corresponds to the Mediterranean area (fig. 1). A detailed description of the available evidence in that region and a discussion about its possible geodynamic implications are given by Mantovani et al. (1997, 2002, 2006a) and Mantovani (2005). In this section, we point out some major aspects of the Pliocene-Quaternary Mediterranean deformation pattern which may lead to define quantitative constraints on the average Nubia-Eurasia relative motion during that period.

\subsection{Eastern Mediterranean}

It is widely recognized that during the Pliocene and Quaternary the northern oceanic margin of Nubia, the Ionian-Levantine Neotethys domain, has subducted under the Anatolian-Aegean system, which has extruded $\mathrm{W}$ to $\mathrm{SW}$-ward with respect to Eurasia in response to the indentation of the Arabian promontory (e.g.,
McKenzie, 1978; Dewey and Sengor, 1979; Robertson, 2000; Aksu et al., 2005). The related consuming boundary (fig. 1) is formed by thrust fronts oriented SE-NW, such as the Hellenic and Pytheus-Cyprus trenches, and left-lateral transpressive fault systems trending SWNE, such as the Pliny-Strabo in the Aegean Arc and the Tartus-Latakia, Larnaka-Amanos and Kyrenia-Misis ones in the Cyprus Arc (e.g., Le Pichon et al., 1981; Kempler and Garfunkel, 1994; Chaumillon and Mascle, 1997; Mascle and Chaumillon, 1997; Papazachos and Papaioannou, 1999; Robertson, 2000; Vidal et al., 2000; Hall et al., 2005a,b; Wdowinski et al., 2006). The orientation of these major tectonic features indicates that Nubia and the AegeanAnatolian system have converged along a roughly SW-NE to SSW-NNE direction in the Pliocene and Quaternary, as recognized by several authors (e.g., Aksu et al., 2005 and references therein).

To understand what implications this evidence may have on the Nubia-Eurasia convergence trend, one should know the coeval kinematics of the Anatolian-Aegean system with respect to the same reference frame. As regards motion trends, most authors agree that in the Pliocene and Quaternary Anatolia has moved roughly westward and Aegea roughly SW-ward with respect to Eurasia (e.g., Le Pichon and Angelier, 1979; Hempton, 1987; Barka, 1992; Armijo et al., 1999, 2003). Analyses of geological offsets along the North Anatolian Fault (NAF) provide values of right-lateral motion rate ranging between 5 and $10 \mathrm{~mm} / \mathrm{yr}$ (e.g., Barka, 1992; Dhont et al., 1998; Hubert-Ferrari et al., 2002; Polonia et al., 2004). Comparable values of slip rate $(10 \mathrm{~mm} / \mathrm{yr})$ are suggested by the recurrence times of major seismic activations of the entire NAF (e.g., Barka, 1992, 1996). Estimates of fault offsets at the Eastern Anatolian fault system (e.g., Cetin et al., 2003) suggest an average slip rate of $11 \mathrm{~mm} / \mathrm{yr}$ in the last 2.5 Myr.

Much higher velocities are indicated by geodetic observations, which suggest $15-25 \mathrm{~mm} / \mathrm{yr}$ for Anatolia and 30-40 mm/yr for Aegea (e.g., McClusky et al., 2000). However, one should be aware that geodetic velocities are only representative of present-day plate motions. The fact that 


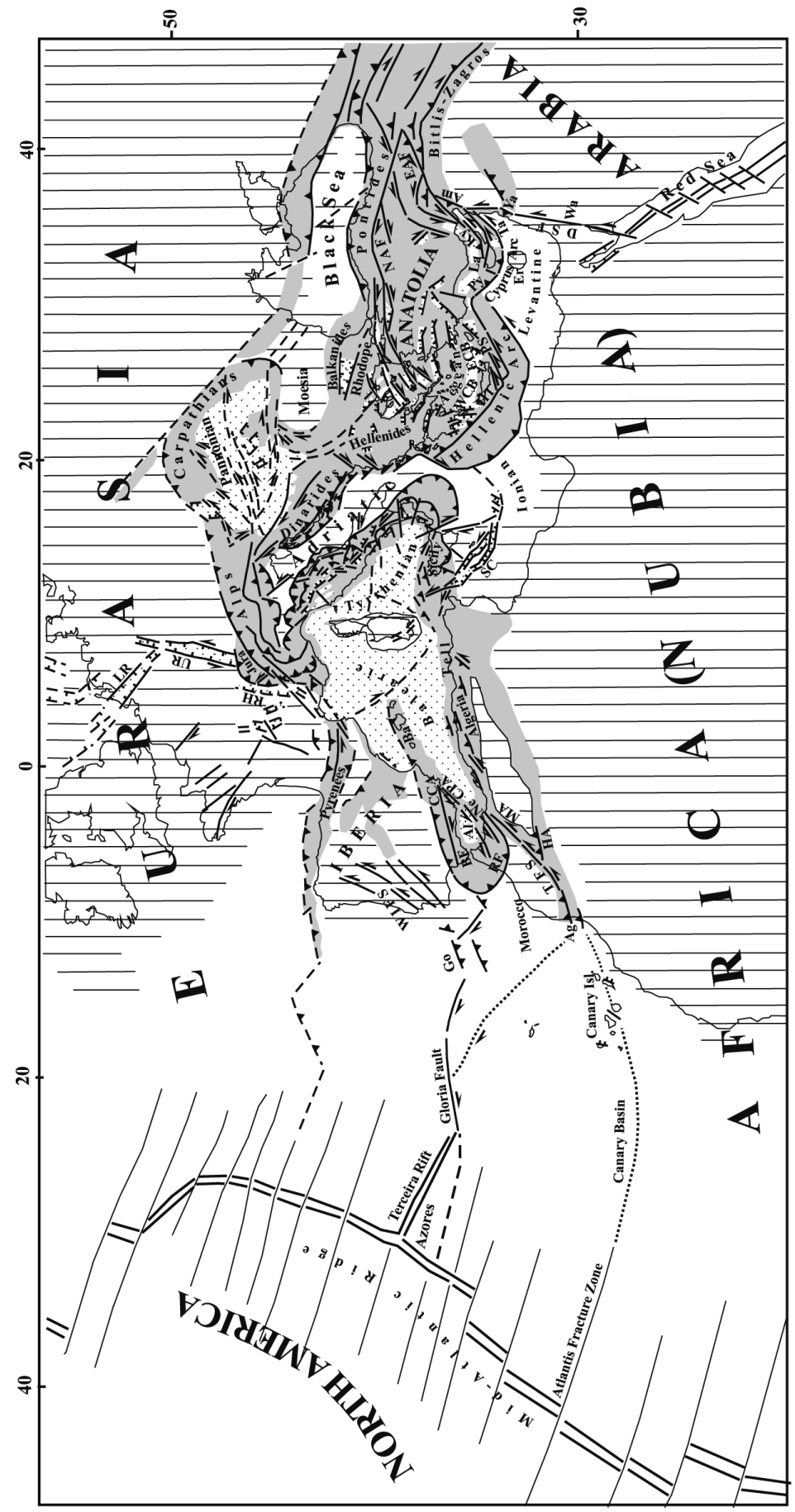

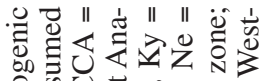

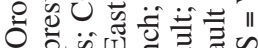

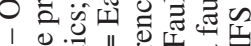

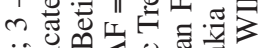

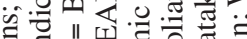
至 ڤै

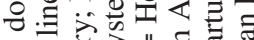

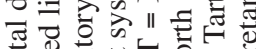

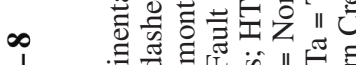

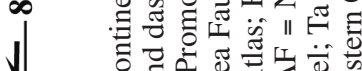
ส

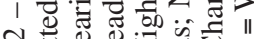
- ํํㅇำ 揞

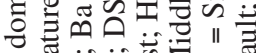

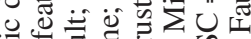

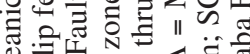
ঠ்

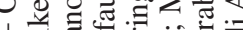

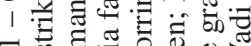

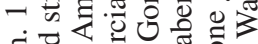
n n

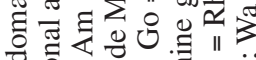

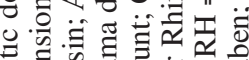

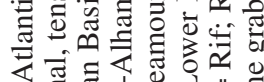

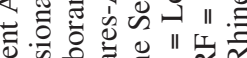

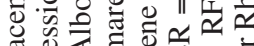

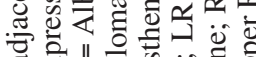
ช ซี

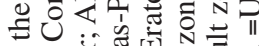

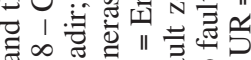

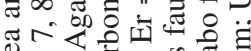
ปี ส केष्य

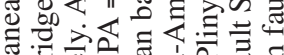
츤

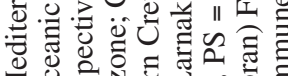

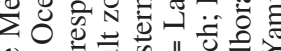

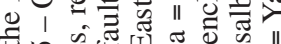
$\leftarrow$ in

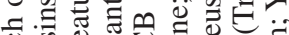

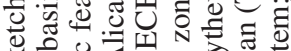

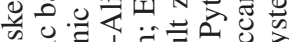

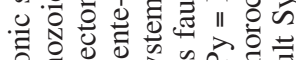

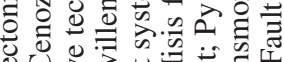

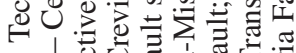

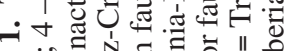

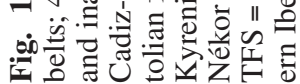


such motions do not coincide with the long-term geological ones should not be a surprise, since it is reasonable to expect significant effects of postseismic relaxation in the Anatolian-Aegean zones after the last strong seismic activation of the North Anatolian decoupling fault system (e.g., Barka et al., 1992, 1996). In particular, one can presume a progressive migration of maximum velocities from Eastern Anatolia to the Aegean region, with a migration rate controlled by the rheological properties of the structures involved. The quantification of post-seismic relaxation induced by the activation of the NAF since the 1939 Erzincan earthquake (Mantovani et al., 2001b; Cenni et al., 2002) predicts that at present the Aegean zone is moving faster than Anatolia, with respective motion rates that fairly agree with the geodetic velocity field. Another reason to believe that the geodetic velocity field in the Aegean region is significantly different from the one which occurred during the Pliocene-Quaternary time is that such field, almost homogeneous (e.g., McClusky et al., 2000; Nyst and Thatcher, 2004), can hardly account for the occurrence of extension in the Eastern and Western Cretan basins (fig. 1), which are the most stretched areas of the Aegean region (Angelier et al., 1982; Li et al., 2003).

On the basis of the arguments mentioned above, it seems highly probable that in the Pliocene-Quaternary the Aegean zone moved SW ward at a rate comparable to that of Nubia. If so, the orientation of trenches and strike-slip faults at the Hellenic boundary zone can hardly be explained if a coeval Nubia-Eurasia motion trend significantly different from NE to NNE-ward is assumed. This conclusion is also suggested by the Plio-Quaternary evolution of the Cyprus Arc, in particular by the fact that in such arc tectonic activity has slowed down considerably since the Pliocene, after collision of the arc with the Eratosthenes continental fragment (e.g., Robertson, 1998; Vidal et al., 2000; Galindo-Zaldivar et al., 2001). Furthermore, one could note that in the Cyprus Arc there is no discrepancy between long and short-term behaviour since geodetic measurements (e.g., Kahle et al., 2000; McClusky et al., 2000; Wdowinsky et al., 2006) indicate a convergence rate (9-14 mm/yr) comparable to the estimated motion rate of Nubia. Thus, assuming a NE to NNE ward motion of Nubia during the Pliocene-Quaternary period seems to be the only possibility to explain the morphology of the Cyprus Arc.

\subsection{Central Mediterranean}

An important constraint on the Nubia-Eurasia kinematics can be inferred from the AdriaEurasia relative motion, since no significant decoupling zone can be recognized between Nubia and Adria since the late Pliocene/Early Pleistocene (e.g., Babbucci et al., 2004; Mantovani, 2005; Argnani, 2006; Mantovani et al., 2006a). The fact that the motion of Adria with respect to Eurasia suggested in the literature (e.g., Anderson and Jackson, 1987), involving a roughly NNE ward motion of the Southern Adriatic region, is not compatible with the NNW ward motion of Nubia predicted by the NUVEL-1 model led a number of authors to look for a decoupling zone between Nubia and Adria (e.g., Anderson and Jackson, 1987; Westaway, 1990; Console et al., 1993; Favali et al., 1993; Oldow et al., 2002; Battaglia et al., 2004; Serpelloni et al., 2005). However, the considerable dispersion of the decoupling zones so far proposed, concerning location (from the Central Adriatic Sea to Eastern Sicily), trend (from S-N to WSW-ENE) and tectonic nature (from strike slip to extensional), underlines the ambiguity of the respective supporting evidence (Argnani et al., 2001; Babbucci et al., 2004; Argnani and Bonazzi, 2005; Argnani, 2006). Significant seismotectonic activity is recognized in the Gargano zone, belonging to the Apulian structural high, but no evident eastward prosecution of this activity is recognized in the Southern Adriatic region (Argnani, 2006). A similar consideration has been made for the presence of minor deformation, with folds and reverse faults, in the offshore of Central Italy (Argnani and Frugoni, 1997). Strike slip faults possibly associated with seismicity are recognized south of the Salento peninsula, but also in this case a Adria-Nubia decoupling zone can hardly be recognized since in the Southernmost Adriatic domain Plio-Quaternary sediments are almost undeformed (Argnani et al., 2001). 
The NNE ward motion trend of southernmost Adria (e.g., Anderson and Jackson, 1987; Babbucci et al., 2004) and the lack of decoupling between Nubia and Adria indicate a motion trend of Nubia in the Central Mediterranean region that is consistent with the NNE ward NubiaEurasia convergence suggested by the geometry of the Hellenic and Cyprus boundary zones. This Nubia's kinematics is also quantitatively supported by the results of numerical modelling (Mantovani et al., 2001c, 2006b), which show that the strain field in the central-eastern Mediterranean region, deduced from neotectonic and seismological data, is satisfactorily reproduced when kinematic boundary conditions are constituted by a NNE ward motion of Nubia and a westward motion of Anatolia.

\subsection{Western Mediterranean}

A significant constraint on the Nubia-Eurasia relative motion can be inferred from the seismotectonics of the Transmoroccan (or Transalboran) fault system. Some authors (e.g., Jacobshagen,
1992 and references therein; Andeweg and Cloetingh, 2001) recognize that this fault system develops from the Betic region in Southern Spain to Agadir in Southern Morocco, crossing the Alboran Sea and the Middle and High Atlas belts (fig. 1). In spite of the fact that this tectonic feature is composed of many single faults, it is widely recognized as a continuous sinistral strike-slip decoupling zone between Nubia and the Morocco microplate (e.g., Jacobshagen, 1992; Andeweg and Cloetingh, 2001).

Detailed investigations on the left-lateral fault pattern along the Transmoroccan belt (fig. 1) reveal the presence of NNE-SSW to NE-SW faults crossing the Betic-Alboran-Rif domain (e.g., Hatzfeld et al., 1993; Medina, 1995; AitBrahim et al., 2002, 2004; Faulkner et al., 2003; Gracia et al., 2006), NE-SW faults in the Middle Atlas, locally associated with extensional and compressional features (e.g., Brede, 1992; Bernini et al., 2000, Gomez et al., 1996, 1998) and ENE-WSW trending transpressional features between the High Atlas and Agadir (e.g., Brede et al., 1992; Mustaphi et al., 1997; Sebrier et al., 2006). Present activity along this

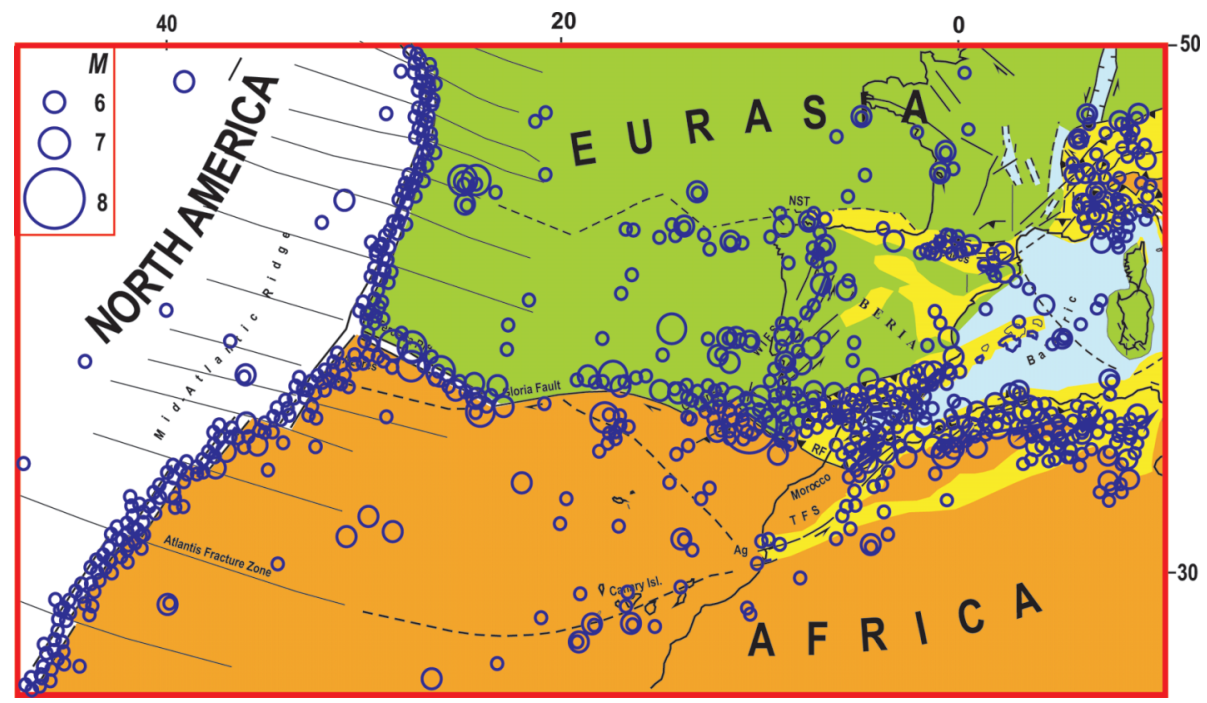

Fig. 2. Seismicity distribution in the Western Mediterranean-Atlantic region $(M>4.5,1964-2006)$ from the database of the Incorporated Researcher Institutions for Seismology (IRIS), available at <http://www.iris.washington.edu $>$. NST=North Spanish Trench; TFS=Transmoroccan Fault System. 
major fracture is testified by crustal and subcrustal seismicity (e.g., Medina and Cherkaoui, 1991; Deffontaines et al., 1992; Lopez-Casado et al., 2001; El Alami et al., 2004), as shown in fig. 2. The existence of a deep decoupling zone between Nubia and Morocco is also suggested by the presence throughout the Atlas belt of abundant Pliocene-Quaternary alkaline basaltic volcanism (e.g., Harmand and Moukadiri, 1986; El Azzab and Wartiti, 1998; Piqué et al., 1998; El Azzouzi et al., 1999).

Some authors (e.g., Anguita and Hernan, 1975, 2000; Brede et al., 1992; Mezcua et al., 1992), on the basis of geological, seismological and volcanological evidence, suggest that the Transmoroccan fault system further propagates West to SW ward through the Canary islands, up to longitude $25^{\circ} \mathrm{W}$ in the Canary basin close to the Hierro and Atlantis mid-Atlantic fracture zones reported by Banda et al. (1992) and Ranero et al. (1997).

The occurrence of a major active deep fracture, like the Transmoroccan one, raises an important problem for global kinematic models, since it is not compatible with the two-plate configuration adopted by those models. Attempts at reconciling the left-lateral shear observed at that fault system with the NW ward Nubia-Eurasia convergence trend predicted by the NUVEL-1 model (e.g., Piqué et al., 1998; Bernini et al., 2000; Andeweg and Cloetingh, 2001) suggest that this feature is due to the west to SW ward extrusion of the Morocco microplate with respect to Eurasia. However, this explanation presents obscure aspects, mainly related to the fact that the active boundaries of the invoked Morocco block are not defined. For instance, the proposed kinematics of this microplate would require shortening somewhere in the adjacent Atlantic zone, which is not recognized. In addition, the presumed westward motion of the Morocco block with respect to Eurasia is not compatible with the NW to NNW ward relative motion between the Moroccan offshore zone and Eurasia, indicated by the structural and seismotectonic features of the Gorringe thrust zone (fig. 1). The above hypothesis about the kinematics of the Morocco microplate could be influenced by another contemporaneous tectonic process which is taking place in that zone, i.e. the westward es- cape of the Betic-Rif orogenic wedge with respect to the surrounding regions (fig. 1). However, this small orogenic wedge, characterized by well recognized active boundaries and only involving shallow structures (e.g., Rebai et al., 1992; Buforn et al., 1995; Meghraoui et al., 1996; Maldonado et al., 1999), should not be confused with the much larger Morocco microplate. On the other hand, a relative motion between the Betic-Rif wedge and the Morocco microplate is well documented by the compressional deformation recognized at the border between these two blocks (e.g., Moratti et al., 2003; Bargach et al., 2004; Medialdea et al., 2004).

The Mediterranean evidence described in this section and the arguments reported by Mantovani et al. (1997, 2002, 2006a) and Mantovani (2005) suggest that in the last few million years Nubia and Eurasia have undergone a SSW-NNE convergence. A similar kinematics is suggested by other authors (e.g., Dercourt et al., 1986; Cetin et al., 2003; Hall et al., 2005a; Aksu et al., 2005 and references therein).

\section{Iberia and Morocco microplates}

In our opinion, the fact that the analysis of North Atlantic data led to a Nubia-Eurasia convergence trend (NNW ward, see e.g., De Mets et al., 1990) significantly different from the one suggested by the Mediterranean evidence (NNE ward) is due to the oversimplified two-plates configuration adopted by the NUVEL-1 approach. This hypothesis is suggested by the occurrence of seismotectonic activity in some zones lying inside the Africa and Eurasia blocks adopted by DeMets et al. (1990), such as the Pyrenees, Western Iberia, Morocco and the adjacent Atlantic region (fig. 2). In particular, we argue that seismotectonic evidence in the Western Mediterranean suggests the presence of at least two major intervening microplates, Morocco and Iberia (fig. 3).

The Morocco (MOR) microplate is delimited by the Azores-Gibraltar tectonic belt, the CanaryTransmoroccan fault system, and by the sector of the Mid Atlantic Ridge running from Azores to the Atlantis fracture zone (fig. 3). The decoupling of this microplate from Nubia is accommodated by overall sinistral strike-slip motion at the $\mathrm{Ca}$ - 


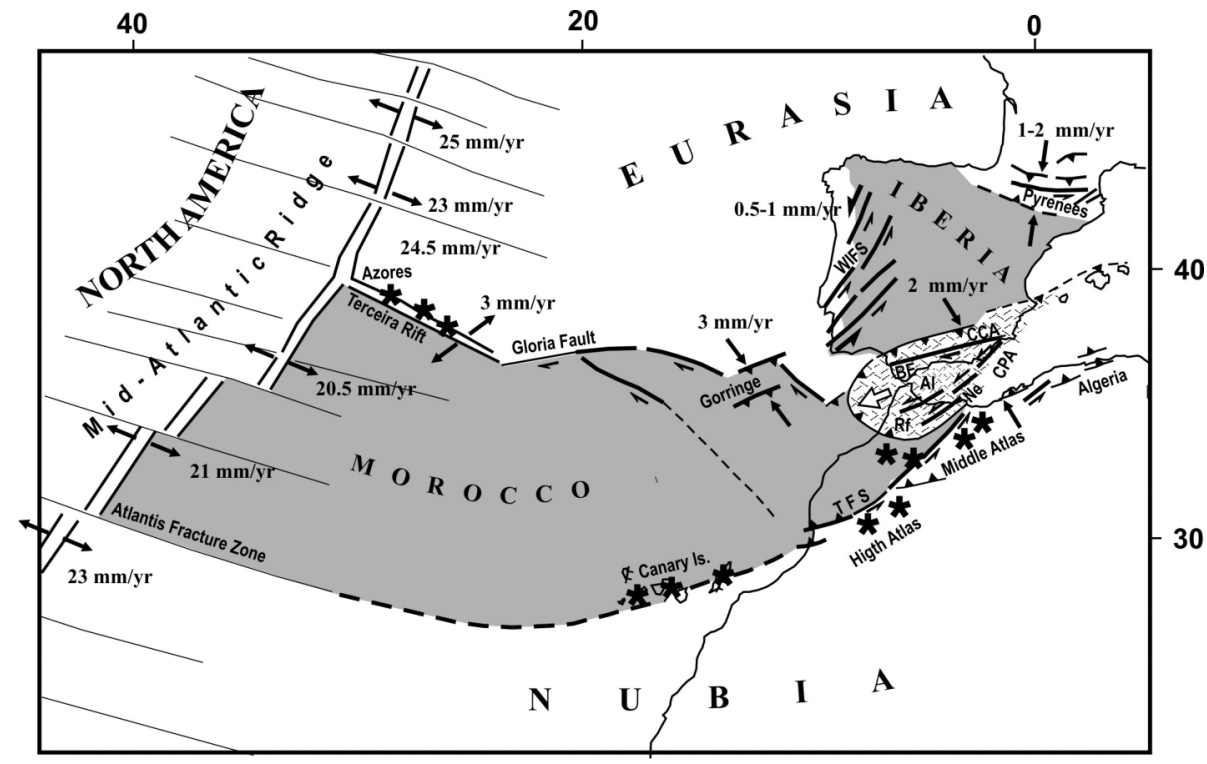

Fig. 3. Geometry of the Iberia and Morocco microplates (shaded areas) and the respective boundaries zones with respect to Nubia and Eurasia. Thick and dashed lines indicate seismically active and presumed plate boundaries, respectively. The stippled zone identifies the Betic-Rif orogenic wedge (extruding westward, as indicated by the empty arrow). Black stars indicate Pliocene-Quaternary alkaline-basaltic volcanism (see text for references). The strain regimes recognized at the various plate boundaries (see table IIa-i) are indicated by converging, diverging and anti-parallel arrows, respectively. Symbols and abbreviations as in fig. 1.

nary-Transalboran fault system, locally transtensional or transpressional as discussed in Section 2. The tentative westward prosecution of this fault system to the Mid Atlantic transform zones, such the Atlantis one, is suggested by the spatial distribution of seismicity (e.g., Wysession et al., 1995 and fig. 2). The decoupling between MOR and Eurasia is accommodated by tectonic activity at the Azores-Gibraltar tectonic belt, NE-SW lengthening at the Terceira ridge, dextral strikeslip at the Gloria fault and roughly NNW-SSE thrusting at the Gorringe zone (e.g., Buforn et al., 1988, 2004; Kiratzi and Papazachos, 1995; Morel and Meghraoui, 1996; Hayward et al., 1999). Roughly E-W lengthening occurs along the sector of the Mid Atlantic Ridge, which forms the boundary between MOR and North America (e.g., DeMets et al., 1990 and references therein). Seismic activity (Lynnes and Ruff, 1985; Buforn et al., 1988) suggests that some dextral strike-slip deformation occurs within MOR, along a NNW-
SSE belt running from the Gloria Fault to Agadir (figs. 2 and 3).

The relative motion between the Iberia (IBE) microplate and Eurasia is accommodated by roughly N-S shortening, accompanied by minor sinistral strike-slip, at the Pyrenean belt (e.g., Grellet et al., 1993; Goula et al., 1999; Pauchet et al., 1999; Mauffret et al., 2001; Alasset and Meghraoui, 2005), and by sinistral shear at the NNE-SSW trending fault system (WIFS in fig. 3) recognized in the Portugal region (e.g., Cabral, 1989; Ribeiro et al., 1996; Jabaloy et al., 2002; Vilanova and Fonseca, 2004; Martinez-Diaz et al., 2006). Both the above borders are affected by significant seismic activity (Souriau and Pauchet, 1998; Souriau et al., 2001; Borges et al., 2001).

The oblique convergence between IBE and Nubia is accommodated by overall NNW-SSE to NW-SE shortening in a relatively large and complex deforming zone (fig. 3), including the Betic- 
Rif orogenic belt, the Alboran zone, the Balearic promontory and the Maghrebian belt in Northern Algeria (e.g., Meghraoui et al., 1986, 1996; Rebai et al., 1992; Buforn et al., 1995, 2004; Morel and Meghraoui, 1996; Stich et al., 2003, 2006; Yelles-Chaouche et al., 2006). The westward extrusion of the Betic-Rif wedge is one of the effects of the IBE-Nubia convergence. The relative motion between IBE and that wedge is accommodated by ENE-WSW dextral transpressional faults in Southern Spain, such as the Cadiz-Crevillente-Alicante, one (e.g., Buforn et al., 1995; Alfaro et al., 2002; Gracia et al., 2006). The decoupling of the Betic-Rif wedge from Nubia is allowed by NNE-SSW to NE-SW sinistral strikeslip and trans-tensional faults in the Alboran Sea and southeastern Spain, such as the Alhama de Murcia-Palomares-Carboneras system, almost aligned with the Transmoroccan fault system (Andeweg and Cloetingh, 2001; Faulkner et al., 2003; Stich et al., 2003, 2006; Gracia et al., 2006). The above sinistral shear zone could continue in the Eastern Rif, where seismically active features such the Nekor Fault (e.g., Hatzfeld et al., 1993; Medina, 1995; Ait Brahim et al., 2004) are recognized. The roughly E-W extension, recognised from southeastern Spain to eastern Rif through the Alboran Sea (e.g., Buforn et al., 1995, 2004; Medina, 1995; Ait Brahim et al., 2002; Martinez-Martinez et al., 2006; Reicherter and Peters, 2005; Gracia et al., 2006) most probably occurs in the wake of the extruding Betic-Rif wedge. The compressional fronts recognized in the Atlantic offshore of Gibraltar, at the western border of the Betic-Rif wedge (e.g., Maldonado et al., 1999; Moratti et al., 2003; Bargach et al., 2004; Medialdea et al., 2004; Gutscher et al., 2006; Thiebot and Gutscher, 2006) mark the zone where this wedge overthrusts the Morocco microplate.

\section{Proposed kinematic model}

To define the new kinematic model for the Mediterranean Nubia-Eurasia boundary zone we assume a plate configuration (fig. 4) that involves three major blocks, Nubia, Arabia and Eurasia, and two microplates, MOR and IBE, as discussed in the previous section. The Anato-
lian-Aegean and the Rif-Betic systems are considered as extruding orogenic wedges rather than rigid blocks, in line with the interpretation of other authors (e.g., Maldonado et al., 1999; Piper and Perissoratis, 2003; Piper et al., 2006). As discussed earlier, the Adriatic promontory is assumed as connected with Nubia.

Eurasia is taken as a rigid and unique plate in spite of the occurrence of seismotectonic activity in France and the Rhine-Rhone graben system (e.g., Sebrier et al., 1997). We assume that this intraplate deformation is mainly due to the indentation of the Adriatic promontory, as suggested by some authors (e.g., Dezes et al., 2004 and references therein). In particular, the push of Adria in the Eastern Alps (fig. 4) is compatible with the sinistral transtension and NE-SW extension observed at the Upper and Lower Rhine Graben systems respectively (e.g., Plenefisch and Bonjer, 1997; Hinzen, 2003) and with the active NW-SE compression in the eastern Swiss Alps and the Jura belt (e.g., Nivière and Winter, 2000; Persaud and Pfiffner, 2004). This driving mechanism, combined with the push of Iberia, could be also responsible for the compressional regime which affects several zones of France, evidenced by a considerable uplift rate (1-2 mm/yr) of the Massif Central, and the seismotectonic activity of several transcurrent and reverse faults from Brittany to Aquitaine (e.g., Grellet et al., 1993; Dezes et al., 2004; Mazabraud et al., 2005).

The occurrence of significant intraplate deformation in Central Europe and the fact that the relatively complex distribution of strain styles in this zone is consistent with the effects expected from the indentation of the Adriatic promontory could provide further support to the hypothesis that Adria moves in connection with Nubia. If the Northern Adriatic domain were decoupled from the Southern Adriatic/Nubia system and were moving very slowly, as suggested by some authors (e.g., Westaway, 1990; Oldow et al., 2002), it would be quite problematic explaining the occurrence of seismotectonic activity in such a broad region, lying just in front of the Adriatic promontory.

At the Hellenic and Cyprus arcs, Nubia interacts with the Anatolian-Aegean system. Along the Dinarides, Adria interacts with the Carpatho-Pannonian region, which is still char- 


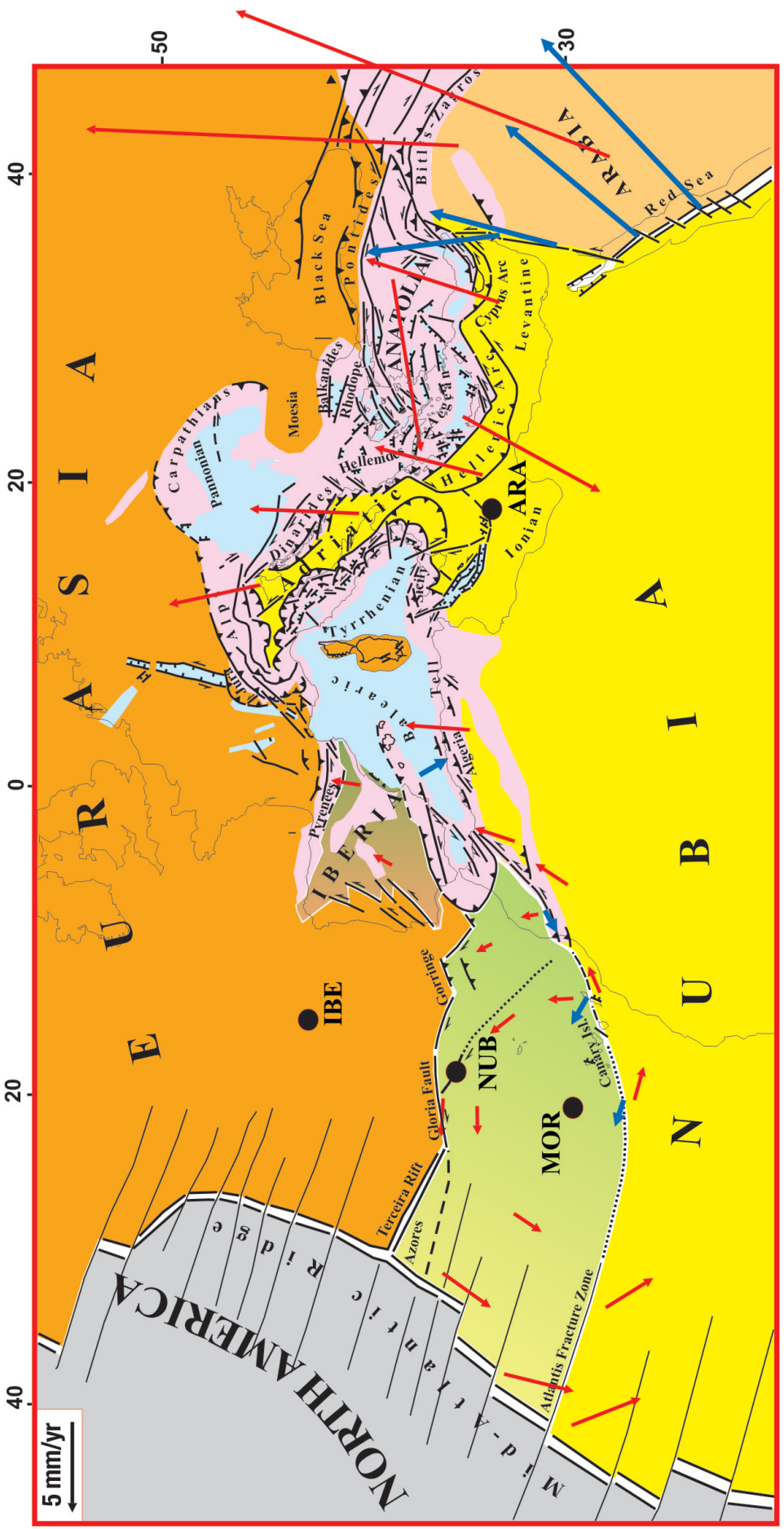

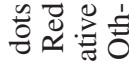

论

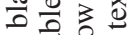

표

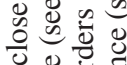

ต ส จ

之学

정

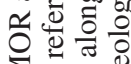

$\sum \approx$ is

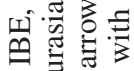

过包光

选

\& $\dot{0} \hat{0}$

을 ญ

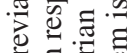

递焉旁

ㅇㅝㅀㅀ

즌

드. 퓽

की

드응

卷 츨

워ㅇㅝㅝ

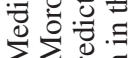

立交

约 $\frac{\pi}{0} \cdot \frac{\pi}{2}$

के 可可

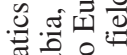

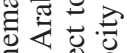

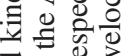

흐월

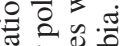

㐫

펑응

$8 \cong$ 넝

능 응

늘

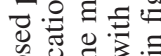

을

은 흥 응

능 응

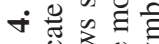

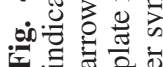


acterized by considerable deformation. Further east, Nubia interacts with the Arabia plate along the mid-ocean-like Red Sea Ridge and the Dead Sea Transform Fault Zone.

Taking into account the plate configuration mentioned above (fig. 4), we looked for the set of Euler poles (table I) which satisfactorily account for the observed features at the various plate borders (table IIa-i), by inverting the available kinematic indicators in a weighted least-square approach (De Mets et al., 1990). The constraints considered in this search are represented by spreading rates (Mid Atlantic Ridge and Red Sea), transform fault azimuths (Mid Atlantic Ridge and Gloria Fault) and relative plate velocity vectors (all other boundaries). Velocity vectors have been obtained from seismic moment tensor summation, structural analysis of neotectonic faults and numerical modelling of recent/ present deformation patterns observed at plate borders (table IIa-i). Given the relatively large uncertainty which may affect the results of these last estimates (e.g., Argus et al., 1989; Marret and Allmendinger, 1990; Viti et al., 2001), we have assigned a relatively large error level $\left(10^{\circ}\right.$ $20^{\circ}$ and $1.5-4 \mathrm{~mm} / \mathrm{yr}$, respectively) to azimuth and rate of velocity vectors.

Kinematic indicators along the Mid Atlantic Ridge, which form the boundary between North America and the Eurasia, Morocco and Nubia blocks are taken from the NUVEL-1 database (DeMets et al., 1990). From the same source also come the kinematic constraints assumed at the Gloria Fault, which in our plate configuration is a sector of the MOR-Eurasia boundary. The western and eastern part of that boundary, i.e. the Terceira rift and the Gorringe thrust zone are instead constrained by seismotectonic velocity vectors (table IIe). The relative motion at the MOR-Nubia boundary is constrained by 6 velocity vectors, two located offshore $(\mathrm{Ca}-$ nary Basin and Canary Islands) and four along the long NE-SW Transmoroccan tectonic belt (Agadir, Tizi n'Test Fault, High Atlas and Middle Atlas). Since these vectors are inferred from the geometrical pattern of faults, folds and joints, only the azimuth of the relative plate motion is defined (table IIg). The relative motion at the IBE-Eurasia boundary is tentatively constrained by two velocity vectors derived from neotectonic faulting, one located in the Western Iberian fault system and the other in the Pyrenean orogenic belt (fig. 3). Along the NubiaIBE boundary, we use one velocity vector, representative of the shortening axis recognized in the wide collision zone from Southern Spain to the Algerian Maghrebian belt.

As discussed in Section 2, we think that a significant constraint on the Nubia-Eurasia relative motion can be deduced from the motion of Adria, that we take as a promontory of Nubia. The constraints we adopt in this zone are represented by two velocity vectors, located in the northern and southern parts of Adria (fig. 4 and table IIf), which are taken from the velocity field derived by numerical experiments (Mantovani et al., 2001c).

Table I. Relative Euler poles (latitude, longitude and angular velocity) of the plates shown in fig. 4, obtained by inverting the kinematic indicators reported in table IIa-i. ARA = Arabia; EUR = Eurasia; IBE = Iberia; MOR= $=$ Morocco $; \mathrm{NAM}=$ North America; NUB $=$ Nubia . See text for explanations.

\begin{tabular}{|c|c|c|c|c|c|c|c|c|c|c|c|c|c|}
\hline & \multicolumn{3}{|c|}{ EUR } & \multicolumn{3}{|c|}{ NAM } & \multicolumn{2}{|r|}{ NUB } & \multicolumn{2}{|r|}{ MOR } & \multicolumn{3}{|c|}{ ARA } \\
\hline & $\begin{array}{l}\text { Lat } \\
\left(^{\circ}\right)\end{array}$ & $\begin{array}{c}\text { Long } \\
\left({ }^{\circ}\right)\end{array}$ & $\begin{array}{c}\omega \\
(\% / \mathrm{Ma})\end{array}$ & $\begin{array}{l}\text { Lat } \\
\left({ }^{\circ}\right)\end{array}$ & $\begin{array}{l}\text { Long } \\
\left({ }^{\circ}\right)\end{array}$ & $\begin{array}{c}\omega \\
(\% / \mathrm{Ma})\end{array}$ & $\begin{array}{l}\text { Lat } \\
\left({ }^{\circ}\right)\end{array}$ & $\begin{array}{l}\text { Long } \omega \\
\left(^{\circ}\right)\left({ }^{\circ} / \mathrm{Ma}\right)\end{array}$ & $\begin{array}{l}\text { Lat } \\
\left({ }^{\circ}\right)\end{array}$ & $\begin{array}{c}\text { Long } \omega \\
\left(^{\circ}\right)\left({ }^{\circ} / \mathrm{Ma}\right)\end{array}$ & $\begin{array}{l}\text { Lat } \\
\left({ }^{\circ}\right)\end{array}$ & $\begin{array}{l}\text { Long } \\
\left({ }^{\circ}\right)\end{array}$ & $\begin{array}{c}\omega \\
(\% / \mathrm{Ma})\end{array}$ \\
\hline NAM & 62.4 & 135.8 & -0.200 & & & & & & & & & & \\
\hline NUB & 36.2 & -18.0 & 0.100 & 80.2 & 75.4 & 0.240 & & & & & & & \\
\hline MOR & 28.5 & -21.0 & 0.123 & 79.6 & 36.9 & 0.240 & -0.8 & -29.70 .028 & & & & & \\
\hline ARA & 34.4 & 18.0 & 0.500 & 50.5 & 30.5 & 0.595 & 32.5 & 25.80 .416 & 33.7 & 29.70 .403 & & & \\
\hline IBE & 43.5 & -14.2 & 0.074 & 76.8 & 105.6 & 0.234 & -16.5 & 154.50 .029 & -8.0 & 152.40 .056 & -32.2 & -157.5 & 50.435 \\
\hline
\end{tabular}


Table IIa-i. Mediterranean and North Atlantic constraints (ridge spreading rates, transform fault azimuths and plate velocity vectors) considered in the search of the kinematic solution reported in table I. For each plate boundary (see figs. 3 and 4), the relevant kinematic constraints, along with the related standard deviation $\sigma$ and the respective values predicted by the related Euler pole (table I), are reported. The differences between predicted and observed values are given in brackets. See text for explanations.

\section{(a) North America - Eurasia}

Spreading rates - Mid-Atlantic Ridge

\begin{tabular}{|c|c|c|c|c|}
\hline Latitude $\left(^{\circ}\right)$ & Longitude $\left(^{\circ}\right)$ & Observed $\pm \sigma(\mathrm{mm} / \mathrm{a})$ & Predicted (mm/a) & Source \\
\hline 86.50 & 43.00 & $12 \pm 3$ & $10.4(-1.6)$ & DeMets et al. (1990) \\
\hline 84.90 & 7.50 & $13 \pm 3$ & $11.5(-1.5)$ & $=$ \\
\hline 84.10 & 00.00 & $13 \pm 2$ & $11.8(-1.2)$ & $=$ \\
\hline 83.40 & -4.50 & $15 \pm 3$ & $12.1(-2.9)$ & $=$ \\
\hline 73.70 & 8.50 & $17 \pm 4$ & $14.1(-2.9)$ & $=$ \\
\hline 72.50 & 3.00 & $15 \pm 4$ & $14.7(-0.3)$ & $=$ \\
\hline 71.80 & -2.50 & $14 \pm 3$ & $15.1(+1.1)$ & $=$ \\
\hline 69.60 & -16.00 & $17 \pm 2$ & $16.1(-0.9)$ & $=$ \\
\hline 69.30 & -16.00 & $17.5 \pm 2$ & $16.2(-1.3)$ & $=$ \\
\hline 68.50 & -18.00 & $18 \pm 2$ & $16.5(-1.5)$ & $=$ \\
\hline 67.90 & -18.50 & $18 \pm 2$ & $16.6(-1.4)$ & $=$ \\
\hline 61.60 & -27.00 & $19 \pm 2$ & $18.3(-0.7)$ & $=$ \\
\hline 60.20 & -29.10 & $19 \pm 2$ & $18.6(-0.4)$ & $=$ \\
\hline 44.50 & -28.20 & $25 \pm 4$ & $21.2(-3.8)$ & $=$ \\
\hline 43.80 & -28.50 & $24 \pm 3$ & $21.3(-2.7)$ & $=$ \\
\hline 43.30 & -29.00 & $23 \pm 3$ & $21.3(-1.7)$ & $=$ \\
\hline 42.90 & -29.30 & $25.5 \pm 2$ & $21.4(-4.1)$ & $=$ \\
\hline 42.70 & -29.30 & $23 \pm 2$ & $21.4(-1.6)$ & $=$ \\
\hline 42.30 & -29.30 & $23.5 \pm 2$ & $21.4(2.1)$ & $=$ \\
\hline 41.70 & -29.20 & $24.5 \pm 3$ & $21.5(-3.0)$ & $=$ \\
\hline
\end{tabular}

Transform azimuths - Mid-Atlantic Ridge

\begin{tabular}{ccccc}
\hline Latitude $\left({ }^{\circ}\right)$ & Longitude $\left({ }^{\circ}\right)$ & Observed $\pm \sigma\left(^{\circ}\right)$ & Predicted $\left(^{\circ}\right)$ & Source \\
\hline 80.00 & 1.00 & $125.5 \pm 5$ & $124.7(-0.8)$ & DeMets et al. $(1990)$ \\
78.80 & 5.00 & $127 \pm 10$ & $126.8(-0.2)$ & $=$ \\
71.30 & -9.00 & $114 \pm 3$ & $112.6(-1.4)$ & $=$ \\
52.60 & -33.20 & $95.9 \pm 3$ & $95.6(-0.3)$ & $=$ \\
52.10 & -30.90 & $95.5 \pm 2$ & $96.8(1.3)$ & $=$ \\
\hline
\end{tabular}

\section{(b) North America - Nubia}

Spreading rates - Mid-Atlantic Ridge

\begin{tabular}{ccccc}
\hline Latitude $\left({ }^{\circ}\right)$ & Longitude $\left({ }^{\circ}\right)$ & Observed $\pm \sigma(\mathrm{mm} / \mathrm{a})$ & Predicted $(\mathrm{mm} / \mathrm{a})$ & Source \\
\hline 29.60 & -43.00 & $23 \pm 3$ & $24.3(+1.3)$ & DeMets et al. $(1990)$ \\
\hline
\end{tabular}


Table IIa-i (continued).

\begin{tabular}{ccccc}
\hline \hline \multicolumn{5}{c}{ Spreading rates - Mid-Atlantic Ridge } \\
\hline Latitude $\left(^{\circ}\right)$ & Longitude $\left(^{\circ}\right)$ & Observed $\pm \sigma(\mathrm{mm} / \mathrm{a})$ & Predicted $(\mathrm{mm} / \mathrm{a})$ & Source \\
\hline 27.50 & -44.20 & $24 \pm 3$ & $24.7(+0.7)$ & DeMets et al. $(1990)$ \\
26.90 & -44.50 & $26 \pm 4$ & $24.8(-1.2)$ & $=$ \\
26.20 & -44.80 & $22 \pm 3$ & $24.9(+2.9)$ & $=$ \\
25.70 & -45.00 & $24 \pm 4$ & $25.0(+1.0)$ & $=$ \\
25.30 & -45.40 & $22.5 \pm 2$ & $25.1(+2.6)$ & $=$ \\
25.10 & -45.40 & $24.5 \pm 2$ & $25.1(+0.6)$ & $=$ \\
24.50 & -46.10 & $23 \pm 4$ & $25.2(+2.2)$ & $=$ \\
24.20 & -46.30 & $24.5 \pm 2$ & $25.2(+0.7)$ & $=$ \\
23.00 & -45.00 & $25 \pm 4$ & $25.4(+0.4)$ & $=$ \\
22.80 & -45.00 & $25 \pm 2$ & $25.4(+0.4)$ & $=$ \\
\hline
\end{tabular}

Transform azimuths - Mid-Atlantic Ridge

\begin{tabular}{|c|c|c|c|c|}
\hline Latitude $\left(^{\circ}\right)$ & Longitude $\left(^{\circ}\right)$ & Observed $\pm \sigma\left(^{\circ}\right)$ & Predicted $\left(^{\circ}\right)$ & Source \\
\hline 23.70 & -45.70 & $98.0 \pm 2$ & $98.9(+0.9)$ & DeMets et al. (1990) \\
\hline
\end{tabular}

Spreading rates - Mid-Atlantic Ridge

\begin{tabular}{ccccc}
\hline Latitude $\left(^{\circ}\right)$ & Longitude $\left(^{\circ}\right)$ & Observed $\pm \sigma(\mathrm{mm} / \mathrm{a})$ & Predicted $(\mathrm{mm} / \mathrm{a})$ & Source \\
\hline 36.80 & -33.20 & $20.5 \pm 2$ & $20.5(+0.0)$ & DeMets et al. $(1990)$ \\
36.50 & -33.70 & $22 \pm 3$ & $20.6(-1.7)$ & $=$ \\
36.00 & -34.10 & $20 \pm 3$ & $20.8(+0.8)$ & $=$ \\
35.00 & -36.50 & $21 \pm 4$ & $21.2(+0.2)$ & $=$ \\
34.30 & -37.00 & $21 \pm 3$ & $21.4(+0.4)$ & $=$ \\
31.90 & -40.50 & $23 \pm 4$ & $22.2(-0.8)$ & $=$ \\
30.90 & -41.70 & $23 \pm 4$ & $22.5(-0.5)$ & $=$ \\
30.50 & -41.90 & $22 \pm 3$ & $22.6(+0.6)$ & $=$ \\
\hline
\end{tabular}

Transform azimuths - Mid-Atlantic Ridge

\begin{tabular}{ccccc}
\hline Latitude $\left({ }^{\circ}\right)$ & Longitude $\left({ }^{\circ}\right)$ & Observed $\pm \sigma\left(^{\circ}\right)$ & Predicted $\left(^{\circ}\right)$ & Source \\
\hline 35.20 & -35.60 & $104.5 \pm 2$ & $102.5(-2.0)$ & DeMets et al. $(1990)$ \\
33.70 & -38.70 & $104.5 \pm 2$ & $102.4(-2.1)$ & $=$ \\
30.00 & -42.40 & $101.5 \pm 3$ & $101.9(+0.4)$ & $=$ \\
\hline
\end{tabular}

(d) Arabia - Nubia

Spreading rates - Red Sea

\begin{tabular}{ccccc}
\hline Latitude $\left({ }^{\circ}\right)$ & Longitude $\left({ }^{\circ}\right)$ & Observed $\pm \sigma(\mathrm{mm} / \mathrm{a})$ & Predicted $(\mathrm{mm} / \mathrm{a})$ & Source \\
\hline 25.77 & 35.73 & $9.7 \pm 1.6$ & $8.8(-0.9)$ & Chu and Gordon (1998) \\
\hline
\end{tabular}


Table IIa-i (continued).

\begin{tabular}{|c|c|c|c|c|}
\hline Latitude $\left(^{\circ}\right)$ & Longitude $\left(^{\circ}\right)$ & Observed $\pm \sigma(\mathrm{mm} / \mathrm{a})$ & Predicted (mm/a) & Source \\
\hline 25.36 & 36.02 & $10.0 \pm 1.6$ & $9.2(-0.8)$ & Chu and Gordon (1998) \\
\hline 22.22 & 37.86 & $13.6 \pm 0.8$ & $11.8(-1.8)$ & $=$ \\
\hline 22.19 & 37.89 & $10.8 \pm 0.8$ & $11.9(+1.1)$ & $=$ \\
\hline 22.16 & 37.91 & $11.8 \pm 0.8$ & $11.9(+0.1)$ & $=$ \\
\hline 22.13 & 37.97 & $12.7 \pm 0.8$ & $12.0(-0.7)$ & $=$ \\
\hline 21.92 & 37.86 & $12.4 \pm 0.8$ & $12.0(-0.4)$ & $=$ \\
\hline 20.96 & 38.19 & $11.0 \pm 0.8$ & $12.7(+1.7)$ & $=$ \\
\hline 20.94 & 38.23 & $11.6 \pm 0.8$ & $12.8(+1.2)$ & $=$ \\
\hline 20.87 & 38.10 & $12.6 \pm 0.8$ & $12.7(+0.1)$ & $=$ \\
\hline 20.21 & 38.29 & $12.2 \pm 0.8$ & $13.2(+1.0)$ & $=$ \\
\hline 20.02 & 38.42 & $13.8 \pm 0.8$ & $13.4(-0.4)$ & $=$ \\
\hline 20.00 & 38.53 & $12.6 \pm 0.8$ & $13.5(+0.9)$ & $=$ \\
\hline 19.97 & 38.56 & $12.0 \pm 0.8$ & $13.5(+1.5)$ & $=$ \\
\hline 19.94 & 38.61 & $13.2 \pm 0.8$ & $13.5(+0.3)$ & $=$ \\
\hline 19.77 & 38.68 & $13.6 \pm 0.8$ & $13.7(+0.1)$ & $=$ \\
\hline 19.61 & 38.77 & $13.8 \pm 0.8$ & $13.8(+0.0)$ & $=$ \\
\hline 19.58 & 38.81 & $13.0 \pm 0.8$ & $13.8(+0.8)$ & $=$ \\
\hline 19.55 & 38.86 & $14.7 \pm 0.8$ & $13.9(-0.8)$ & $=$ \\
\hline 19.52 & 38.89 & $15.0 \pm 0.8$ & $13.9(-1.1)$ & $=$ \\
\hline 19.39 & 38.95 & $14.0 \pm 0.8$ & $14.0(+0.0)$ & $=$ \\
\hline 19.36 & 38.99 & $14.6 \pm 0.8$ & $14.0(-0.6)$ & $=$ \\
\hline 19.31 & 39.00 & $14.8 \pm 0.8$ & $14.1(-0.7)$ & $=$ \\
\hline 19.28 & 39.05 & $15.0 \pm 0.8$ & $14.1(-0.9)$ & $=$ \\
\hline 19.19 & 39.16 & $14.8 \pm 0.8$ & $14.2(-0.6)$ & $=$ \\
\hline 19.16 & 39.08 & $15.2 \pm 0.8$ & $14.2(-1.0)$ & $=$ \\
\hline 19.06 & 39.30 & $15.2 \pm 0.8$ & $14.4(-0.8)$ & $=$ \\
\hline 19.02 & 39.33 & $15.3 \pm 0.8$ & $14.4(-0.9)$ & $=$ \\
\hline 18.99 & 39.37 & $15.6 \pm 0.8$ & $14.5(-1.1)$ & $=$ \\
\hline 18.95 & 39.40 & $14.6 \pm 0.8$ & $14.9(+0.3)$ & $=$ \\
\hline 18.92 & 39.43 & $15.4 \pm 0.8$ & $14.5(-0.9)$ & $=$ \\
\hline 18.85 & 39.48 & $15.2 \pm 0.8$ & $14.6(-0.6)$ & $=$ \\
\hline 18.82 & 39.53 & $15.4 \pm 0.8$ & $14.6(-0.8)$ & $=$ \\
\hline 18.80 & 39.62 & $15.0 \pm 0.8$ & $14.7(-0.3)$ & $=$ \\
\hline 18.78 & 39.55 & $15.0 \pm 0.8$ & $14.7(-0.3)$ & $=$ \\
\hline 18.74 & 39.59 & $15.2 \pm 0.8$ & $14.7(-0.5)$ & $=$ \\
\hline 18.71 & 39.62 & $14.8 \pm 0.8$ & $14.7(-0.1)$ & $=$ \\
\hline 18.63 & 39.69 & $15.4 \pm 0.8$ & $14.8(-0.6)$ & $=$ \\
\hline 18.55 & 39.75 & $15.2 \pm 0.8$ & $14.9(-0.3)$ & $=$ \\
\hline 18.48 & 39.78 & $15.5 \pm 0.8$ & $14.9(-0.6)$ & $=$ \\
\hline 18.42 & 39.83 & $15.5 \pm 0.8$ & $15.0(-0.5)$ & $=$ \\
\hline
\end{tabular}


Table IIa-i (continued).

\begin{tabular}{ccccc}
\hline \hline Latitude $\left(^{\circ}\right)$ & Longitude $\left(^{\circ}\right)$ & Observed $\pm \sigma(\mathrm{mm} / \mathrm{a})$ & Predicted $(\mathrm{mm} / \mathrm{a})$ & Source \\
\hline 18.35 & 39.88 & $16.1 \pm 0.8$ & $15.1(-1.0)$ & Chu and Gordon (1998) \\
18.31 & 39.79 & $15.2 \pm 0.8$ & $15.1(-0.1)$ & $=$ \\
18.04 & 40.04 & $14.8 \pm 0.8$ & $15.3(+0.5)$ & $=$ \\
17.96 & 40.06 & $15.9 \pm 0.8$ & $15.4(-0.5)$ & $=$ \\
\hline
\end{tabular}

Velocity vectors - Dead Sea fault zone

\begin{tabular}{|c|c|c|c|c|c|c|c|}
\hline Zone & $\begin{array}{l}\text { Latitude } \\
\quad\left({ }^{\circ}\right)\end{array}$ & $\begin{array}{l}\text { Longitude } \\
\left(^{\circ}\right)\end{array}$ & $\begin{array}{r}\text { Obser } \\
\text { Azimuth }\left(^{\circ}\right)\end{array}$ & $\pm \sigma$ & $\begin{array}{r}\text { Predi } \\
\text { Azimuth }\left(^{\circ}\right)\end{array}$ & $\begin{array}{l}\text { cted } \\
\text { Rate (mm/a) }\end{array}$ & Source \\
\hline $\begin{array}{l}\text { Wadi Araba } \\
\text { Fault }\end{array}$ & a 30.8 & 35.4 & - & - & $14.3(-0.7)$ & $6.7(+1.7)$ & Klinger et al. $(2000 \mathrm{a}, \mathrm{b})$ \\
\hline $\begin{array}{l}\text { Yamunneh } \\
\text { Fault }\end{array}$ & 34.0 & 36.0 & $355 \pm 10$ & $7.5 \pm 1.5$ & $353.0(-2.0)$ & $7.0(-0.5) \mathrm{C}$ & $\begin{array}{l}\text { Gomez et al. }(2003,2006) ; \\
\quad \text { Rukieh } \text { et al. }(2005)\end{array}$ \\
\hline
\end{tabular}

(e) Morocco-Eurasia

Transform azimuths - Gloria Fault

\begin{tabular}{ccccc}
\hline Latitude $\left(^{\circ}\right)$ & Longitude $\left(^{\circ}\right)$ & Observed $\pm \sigma\left({ }^{\circ}\right)$ & Predicted $\left(^{\circ}\right)$ & Source \\
\hline 36.90 & -23.50 & $257 \pm 5$ & $255.3(-1.7)$ & DeMets et al. $(1990)$ \\
37.00 & -22.60 & $265 \pm 3$ & $260.6(-4.4)$ & $=$ \\
37.10 & -21.70 & $265 \pm 3$ & $265.9(+0.9)$ & $=$ \\
37.10 & -20.50 & $270 \pm 7$ & $272.9(+2.9)$ & $=$ \\
\hline
\end{tabular}

Velocity vectors

\begin{tabular}{|c|c|c|c|c|c|c|}
\hline Zone & $\begin{array}{l}\text { Latitude } \\
\quad\left({ }^{\circ}\right)\end{array}$ & $\underset{\left({ }^{\circ}\right)}{\text { Longitude }}$ & $\begin{array}{r}\text { Obser } \\
\text { Azimuth }\left(^{\circ}\right)\end{array}$ & $(\mathrm{mm} / \mathrm{a})$ & $\begin{array}{c}\text { Predicted } \\
\text { Azimuth }\left(^{\circ}\right) \text { Rate }(\mathrm{mm} / \mathrm{a})\end{array}$ & Source \\
\hline $\begin{array}{l}\text { Terceira } \\
\text { Rift }\end{array}$ & 38.80 & -27.20 & $45 \pm 20$ & $3 \pm 1$ & $61.6(+16.6) \quad 2.7(-0.3)$ & $\begin{array}{l}\text { Buforn et al. (1988); Kiratzi } \\
\text { and Papazachos (1995) }\end{array}$ \\
\hline $\begin{array}{l}\text { Gorringe } \\
\text { Thrust }\end{array}$ & 36.00 & -10.50 & $340 \pm 20$ & $3 \pm 2$ & $322.7(17.3) * 1.0(-2.0)^{*}$ & Buforn et al. (2004) \\
\hline
\end{tabular}

(f) Nubia - Eurasia

\section{Velocity vectors}

\begin{tabular}{|c|c|c|c|c|c|c|c|}
\hline \multirow{2}{*}{$\begin{array}{l}\text { Zone } \\
\\
\text { South- } \\
\text { eastern } \\
\text { Alps }\end{array}$} & \multirow{2}{*}{$\begin{array}{l}\text { Latitude } \\
\qquad\left(^{\circ}\right) \\
45.80\end{array}$} & \multirow{2}{*}{$\begin{array}{c}\text { Longitude } \\
\left(^{\circ}\right) \\
14.80\end{array}$} & \multicolumn{2}{|c|}{$\begin{array}{l}\text { Inferred from numerical } \\
\text { modelling } \pm \sigma \\
\text { Azimuth }\left({ }^{\circ}\right) \text { Rate }(\mathrm{mm} / \mathrm{a})\end{array}$} & \multicolumn{2}{|c|}{ Predicted } & Source \\
\hline & & & $358 \pm 20$ & $3 \pm 2$ & $350.3(-7.7)$ & $4.9(+1.9)$ & Mantovani et al. (2001c) \\
\hline $\begin{array}{l}\text { Southern } \\
\text { Adriatic }\end{array}$ & 40.50 & 17.60 & $7 \pm 20$ & $5 \pm 3$ & $2.8(-4.2)$ & $5.2(+0.2)$ & $=$ \\
\hline Sirte Basin & 34.64 & 20.40 & $24 \pm 20$ & $8 \pm 4$ & $14.2(-9.8)$ & $5.7(-2.3)$ & $=$ \\
\hline $\begin{array}{l}\text { Levantine } \\
\text { Basin }\end{array}$ & 33.77 & 31.60 & $27 \pm 20$ & $11 \pm 4$ & $18.0(-9.0)$ & $7.2(-3.8)$ & $=$ \\
\hline
\end{tabular}


Table IIa-i (continued).

(9) Nubia - Morocco

Velocity vectors - Canary-Transmoroccan Fault Zone

\begin{tabular}{|c|c|c|c|c|c|c|c|}
\hline Zone & $\begin{array}{l}\text { Latitude } \\
\qquad\left(^{\circ}\right)\end{array}$ & $\begin{array}{l}\text { Longitude } \\
\qquad\left(^{\circ}\right)\end{array}$ & $\begin{array}{r}\text { Observ } \\
\text { Azimuth }\left(^{\circ}\right)\end{array}$ & $\begin{array}{l}=\sigma \\
(\mathrm{mm} / \mathrm{a})\end{array}$ & $\begin{array}{r}\text { Predic } \\
\text { ) Azimuth }\left(^{\circ}\right) \mathrm{I}\end{array}$ & $(\mathrm{mm} / \mathrm{a})$ & Source \\
\hline $\begin{array}{l}\text { Canary } \\
\text { Basin }\end{array}$ & 27.0 & -21.0 & $106 \pm 20$ & - & $108.2(+2.2)$ & 1.50 & Wysession et al. (1995) \\
\hline $\begin{array}{l}\text { Canary } \\
\text { Islands }\end{array}$ & 29.0 & -14.0 & $120 \pm 20$ & - & $119.5(-0.5)$ & 1.70 & $\begin{array}{l}\text { Feraud et al. (1985); } \\
\text { Day et al. (1999); } \\
\text { Marinoni (2001) }\end{array}$ \\
\hline Agadir & 30.5 & -9.7 & $70 \pm 10$ & - & $68.1(-0.9)^{*}$ & $1.4^{*}$ & Sebrier et al. (2006) \\
\hline $\begin{array}{l}\text { TizinTest } \\
\text { Fault }\end{array}$ & 31.0 & -8.0 & $60 \pm 10$ & - & $61.7(+1.7)^{*}$ & $1.4^{*}$ & $\begin{array}{l}\text { Jacobshagen (1992); } \\
\text { Sebrier et al. (2006) }\end{array}$ \\
\hline High Atlas & 31.7 & -6.5 & $60 \pm 10$ & - & $55.8(-4.2)^{*}$ & $1.4^{*}$ & $\begin{array}{c}\text { Brede (1992); } \\
\text { Beauchamp et al. (1999); } \\
\text { Teixell et al. (2003) }\end{array}$ \\
\hline $\begin{array}{l}\text { Middle } \\
\text { Atlas }\end{array}$ & 33.0 & -5.0 & $40 \pm 10$ & - & $48.0(+8.0)^{*}$ & $1.4^{*}$ & $\begin{array}{l}\text { Deffontaines et al. (1992); } \\
\text { Gomez et al. (1996, 1998) }\end{array}$ \\
\hline
\end{tabular}

\section{(h) Nubia - Iberia}

Velocity vectors - Algeria

\begin{tabular}{|c|c|c|c|c|c|c|}
\hline $\begin{array}{l}\text { Latitude } \\
\left(^{\circ}\right)\end{array}$ & $\begin{array}{c}\text { Longitude } \\
\left({ }^{\circ}\right)\end{array}$ & $\begin{array}{r}\text { Obser } \\
\text { Azimuth }\left(^{\circ}\right.\end{array}$ & $\begin{array}{l}\mathrm{d} \pm \sigma \\
\text { ate }(\mathrm{mm} / \mathrm{a})\end{array}$ & $\begin{array}{r}\text { Predic } \\
\text { Azimuth }\left(^{\circ}\right)\end{array}$ & $\begin{array}{l}\text { ed } \\
\text { Rate }(\mathrm{mm} / \mathrm{a})\end{array}$ & Source \\
\hline 36.80 & 3.70 & $325 \pm 10$ & $2 \pm 1$ & $329.6(+4.6)$ & $1.7(-0.3)$ & $\begin{array}{c}\text { Meghraoui and Doumaz (1996); } \\
\text { Buforn } \text { et al. (2004); } \\
\text { Yelles-Chaouche } \text { et al. (2006) }\end{array}$ \\
\hline
\end{tabular}

(i) Iberia - Eurasia

Velocity vectors

\begin{tabular}{cccccccc}
\hline Zone & $\begin{array}{c}\text { Latitude } \\
\left({ }^{\circ}\right)\end{array}$ & $\begin{array}{c}\text { Longitude } \\
\left({ }^{\circ}\right)\end{array}$ & \multicolumn{2}{c}{$\begin{array}{c}\text { Observed } \pm \sigma \\
\text { Azimuth }\left({ }^{\circ}\right) \text { Rate }(\mathrm{mm} / \mathrm{a})\end{array}$} & $\begin{array}{c}\text { Predicted } \\
\text { Azimuth }\left({ }^{\circ}\right) \text { Rate }(\mathrm{mm} / \mathrm{a})\end{array}$ & Source \\
\hline Portugal & 41.0 & -7.0 & $20 \pm 10$ & $<1$ & $27.5(+7.5)$ & 0.8 & $\begin{array}{c}\text { Cabral }(1989) ; \\
\text { Ribeiro } \text { et al. }(1996) ; \\
\text { Jabaloy } \text { et al. }(2002)\end{array}$ \\
Pyrenees & 43.0 & 1.0 & $0 \pm 20$ & $<2$ & $7.9(+7.9)$ & 1.6 & $\begin{array}{c}\text { Herraiz } \text { et al. } \text { (2000); } \\
\text { Alasset and Meghraoui } \\
(2005)\end{array}$ \\
\hline
\end{tabular}

(*) Computed by adopting the $33 \%$ of the Morocco-Eurasia angular velocity reported in table I.

Our confidence in such constraints is based on the fact that the adopted velocity field can quantitatively account for the Quaternary deformation pattern in the central-eastern Mediterranean re- gion inferred from a large amount of geological and geophysical data. We also impose that the Nubian domain lying in front of the Hellenic and Cyprus arcs moves NNE ward, as discussed in 
Section 2. This condition is defined by the velocity vectors located in the Syrte and Levantine basins (table IIf), taken from the velocity field resulting from numerical modelling (Mantovani et al., 2001c). Considering the significant uncertainty which may affect these constraints, we assign them a relatively large error $\left(20^{\circ}\right)$.

The relative motion between Nubia and Arabia is constrained by spreading rates in the Red Sea (Chu and Gordon, 1998) and by velocity vectors deduced by seismological and geological information in two sectors of the Dead Sea fault system (Wadi Araba and Yammuneh fault zones; fig. 1). Chu and Gordon's (1998) dataset allows for a much more reliable computation of the Arabia-Nubia Euler poles with respect to the data used by DeMets et al. (1990), which are all located in Gulf of Aden, now largely believed to represent the Somalia-Arabia plate boundary (e.g., Fournier et al., 2001). In fact, in the Dead Sea shear zone the NUVEL1 model predicts shortening rates considerably larger than those observed (e.g., Klinger et al., 2000a,b; McClusky et al., 2003). The velocity vectors in the Anatolian-Aegean system shown in fig. 4 are consistent with the considerations given in Section 2.1. The motion trends of Anatolia and Aegea are westward and SW ward respectively, as suggested by most authors, while the rates are compatible with the geological evidence discussed in Section 2.1 (5-10 mm/yr).

To better illustrate the plate kinematics predicted by the Euler poles given in table I, both the predicted velocity fields in plate interiors (red arrows) and the relative velocity at plate boundaries (blue arrows) are shown in fig. 4 .

In our opinion, the kinematic solution here proposed can help to overcome several major outstanding problems of the NUVEL-1 NubiaEurasia kinematics:

- For instance, the hypothesis that Nubia has moved NNE ward in the recent history does not require the very unlikely drastic change of motion trend, from NE ward to NW ward, which is instead implied by the Nubia-Eurasia kinematics provided by global kinematic models (see e.g., Dewey et al., 1989). A discussion about this problem is given by Mantovani (2005).

- The two-plates configuration adopted by the NUVEL-1 model cannot account for the oc- currence of intense earthquakes in the Transmoroccan-Canary fault system, in Portugal and in the Pyrenean belt. In particular, the major features of the Transmoroccan tectonic belt, such as the occurrence of sinistral strike-slip faulting, alkaline basaltic volcanism, and strong lithospheric thinning (e.g., Piqué et al., 1998; Seber et al., 1996; Ramdani, 1998; Teixell et al., 2005; Fullea et al., 2007) and the seismotectonic features in the adjacent Atlantic zone can hardly be reconciled with the Nubia-Eurasia relative motion predicted by the NUVEL-1 model.

- The incompatibility between the widely recognized Adria kinematics and the NUVEL-1 Nubia-Eurasia relative motion cannot be reconciled with the lack of a reliable decoupling zone between Nubia and Adria (Babbucci et al., 2004; Argnani, 2006).

- The SW-NE relative motion between Nubia and the Anatolian-Aegean system, implied by the morphological features of the Hellenic and Cyprus arcs, can be reconciled with a NNW ward motion of Nubia only if the Plio-Quaternary motion rate of the Anatolian-Aegean system was much higher than the one of Nubia. However, such hypothesis is not consistent with Pliocene-Quaternary geological evidence in that system.

Furthermore, it must be pointed out that the kinematic pattern we propose (fig. 4) is compatible with many other features of the PlioceneQuaternary deformation pattern observed in the Mediterranean region, as discussed in previous papers (Mantovani et al., 1997, 2002, 2006a; Mantovani, 2005) and supported by the results of numerical modelling (Mantovani et al., 2001c).

On the other hand, it cannot be ignored that our kinematic solution is significantly different from the models derived by geodetic data. A discussion about this possible problem is given in the next section.

\section{Geodetic measurements}

A number of attempts at determining the Nubia-Eurasia relative motion by using space geodetic data have so far been made (e.g., Sella et al., 2002; McClusky et al., 2003; Calais et al., 2003; Kreemer et al., 2003; Nocquet and Calais, 


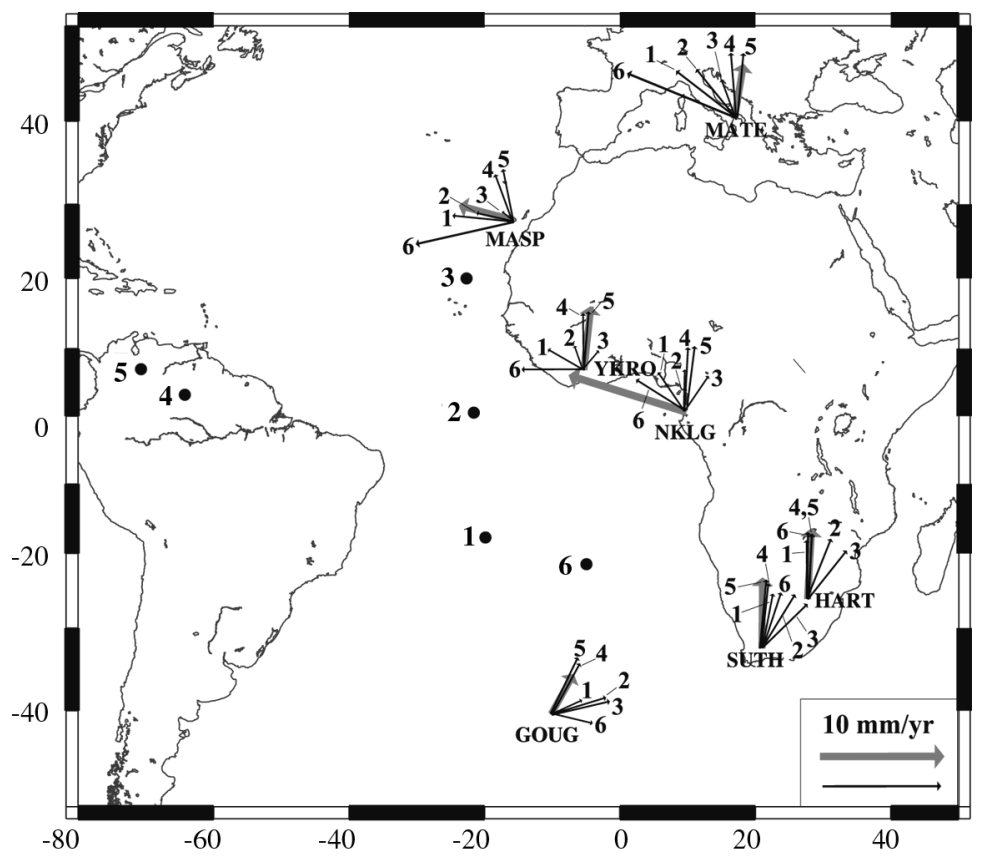

Fig. 5. Nubia-Eurasia Euler poles derived from geodetic data (black dots numbered from 1 to 6 ) and respective velocities (thin arrows with numbers) predicted by such poles at the African GPS sites reported in table IIIa. Thick grey arrows show the residual ITRF2000 velocities (table IIIa) with respect to the Eurasia absolute pole provided by Prawirodirdjo and Bock (2004). Poles 1 to 3 are taken from literature, while the poles 4 to 6 are computed in this work taking into account slightly different data sets with respect to the first 3 poles (see table IIIb).

2004; Prawirodirdjo and Bock, 2004). The Nubia-Eurasia Euler poles proposed by the above authors (some of them are given in fig. 5 and table IIIa,b) considerably differ from one another and are mostly located south of the NUVEL1 pole, implying an even more westward motion trend of Nubia in the Mediterranean region with respect to the model here proposed.

We do not have any simple explanation for the fact that the present-day kinematics inferred from geodetic data is significantly different from the long-term kinematic models, the NUVEL-1 and the one here proposed. One could consider the possibility that such difference is due to a variation of plate kinematics in the recent evolution. For instance, Calais et al. (2003) tentatively relate the presumed recent deviation and slowdown of the Nubia-Eurasia convergence to the increasingly collisional resistance in the Mediter- ranean region. However, even if this explanation cannot be ruled out, it is not easy to believe that the change of motion trend of Nubia from NNE to NNW ward has occurred without leaving clear geological imprints throughout the Mediterranean region (Mantovani, 2005). Even Calais et al. (2003) admit that neither convincing Mediterranean tectonic evidence nor dynamic causes responsible of the above change may easily be recognized. Significant discrepancies between geodetic velocities and global kinematic models have been recognised along other major plate boundaries, as the Andes and the Himalaya-Tibet (Yang and Mian, 2002), but such discrepancies have been tentatively explained as effects of different short and long-term mechanical behaviour of the lithosphere.

In the following, to explore alternative explanations of the short-term/long-term discrep- 
Table IIIa,b. Nubia-Eurasia kinematics from geodetic measurements. a) North (u) and east (v) components of absolute and residual velocity in 7 GPS continuous stations located in Nubia and in the Southern Adriatic (MATE), shown in fig. 5. Absolute velocities and standard deviations $(\sigma)$, are provided by the Laboratoire de Recherches en Géodésie (LAREG), whose ITRF2000 solution is available at <http://lareg.ensg.ign.fr >. Residual velocities are obtained from absolute ones by subtracting Prawirodirdjo and Bock's (2004) Eurasia absolute pole (latitude $57.246^{\circ} \mathrm{N}$, longitude $-99.691^{\circ} \mathrm{E}$ and angular velocity $0.260^{\circ} / \mathrm{Myr}$ ). b) Nubia-Eurasia Euler poles (fig. 5) taken from literature (1,2 and 3) and determined in this work (4, 5 and 6$)$ by the data set reported in a). All the above Nubia-Eurasia Euler poles have been obtained by difference from the related Nubia and Eurasia absolute poles (see text for explanations). For each case, the list of continuous GPS stations used to constrain the Nubia absolute pole is shown. Pole 2 has also been constrained by 1 non-continuous GPS site and 4 sites belonging to the DORIS network (e.g., Willis et al., 2005). The columns «Nubia» and «Eurasia» report basic information about the absolute Euler poles from which the above Nubia-Eurasia poles derive. $N$ is the number of geodetic stations used to constrain the respective absolute Euler pole, $v=2 N-3$ is the related number of degrees of freedom, and $\chi_{v}^{2}$ is the reduced $\chi^{2}$ error (e.g., Kreemer et al., 2003).

\begin{tabular}{|c|c|c|c|c|c|c|c|c|c|c|c|}
\hline (a) & Station & & & & osolut & vel & locity & & Residu & lual veloc & \\
\hline & ame & Lat $\left({ }^{\circ}\right)$ & Long $\left({ }^{\circ}\right)$ & $u(\mathrm{~mm} / \mathrm{yr})$ & $\pm \sigma$ & $v(\mathrm{r}$ & $\mathrm{mm} / \mathrm{yr}) \pm \sigma$ & & $(\mathrm{mm} / \mathrm{yr})$ & $v(\mathrm{ml}$ & $\mathrm{m} / \mathrm{yr})$ \\
\hline & DUG & -40.35 & -9.88 & $18.51 \pm 3$ & 60 & & $.23 \pm 1.89$ & & 2.87 & & 61 \\
\hline $\begin{array}{r}\text { HART }(\mathrm{H} \\
\text { HARK }\end{array}$ & $\begin{array}{l}\text { IAR, HARB, } \\
\text {, HRAO) }\end{array}$ & -25.89 & 27.71 & $17.86 \pm 0$ & .41 & & $3.09 \pm 0.35$ & & 5.43 & & 32 \\
\hline MASP (N & MAS, MAS1) & 27.76 & -15.63 & $16.67 \pm 0$ & .54 & & $6.66 \pm 0.35$ & & 1.11 & & .13 \\
\hline & ATE & 40.65 & 16.70 & $18.09 \pm 0$ & .36 & & $3.70 \pm 0.13$ & & 4.08 & & 69 \\
\hline & KLG & 0.35 & 9.67 & $17.73 \pm 1$ & .30 & & $1.88 \pm 2.39$ & & 2.97 & & .47 \\
\hline & JTH & -32.38 & 20.81 & $18.92 \pm 1$ & 69 & & $6.39 \pm 1.37$ & & 5.44 & & 05 \\
\hline & KRO & 6.83 & -5.24 & $20.42 \pm 1$ & .10 & & $4.82 \pm 1.10$ & & 4.83 & & 53 \\
\hline (b) Pole & Sourc & ce and $\mathrm{Nu}$ & & Nubia-Eu & rasia 1 & otati & ion vector & Nut & bia & Eurasi & \\
\hline & (a) & detic stati & & Lat $\left({ }^{\circ} \mathrm{N}\right)$ & Lon & & $\omega(\% / \mathrm{Myr})$ & $N, v$ & $\chi_{v}^{2}$ & $N, v$ & $\chi_{\nu}^{2}$ \\
\hline 1 & $\begin{array}{r}\text { Sella et al. }(2 \\
\text { HRAO }\end{array}$ & $\begin{array}{l}\text { 2002): G( } \\
\text {, MAS, S }\end{array}$ & $\begin{array}{l}\text { UG, HAR, } \\
\text { UTH }\end{array}$ & -18.23 & -20 & & 0.062 & 5,7 & 0.82 & 15,27 & 1.02 \\
\hline $\begin{array}{r}2 \mathrm{~K} \\
\mathrm{SL}\end{array}$ & $\begin{array}{r}\text { Kreemer et al. } \\
\text { UTH + MATR } \\
\text { + ARMA, D } \\
\text { (DOF }\end{array}$ & $\begin{array}{l}\text { (2003): } \\
\text { (GPS no } \\
\text { AKA, HI } \\
\text { RIS netw }\end{array}$ & $\begin{array}{l}\text { OUG, MAS, } \\
\text { continuous)+ } \\
\text { LA, LIBA } \\
\text { rk) }\end{array}$ & 1.1 & -21 & & 0.060 & 8,13 & $0.54 \quad 1$ & 122,241 & 1.05 \\
\hline 3 & $\begin{array}{r}\text { Prawirodirdj } \\
\text { GOUG, HAI } \\
\text { MAS1, }\end{array}$ & $\begin{array}{l}\text { ljo and Bc } \\
\text { RB, HAR } \\
\text { NKLG, }\end{array}$ & $\begin{array}{l}\text { ck (2004): } \\
\text { K, HRAO, } \\
\text { UTH }\end{array}$ & 20.09 & -22 & & 0.051 & 7,11 & 0.8 & 18,33 & 1.1 \\
\hline 4 & This work: $\mathrm{G}$ & SOUG, $\mathrm{H}$ & RT, SUTH & 3.21 & -62 & & 0.049 & 3,3 & 0.16 & as Pole & \\
\hline 5 & $\begin{array}{r}\text { This work } \\
\text { SU' }\end{array}$ & $\begin{array}{l}\text { k: GOUG } \\
\text { JTH, YKR }\end{array}$ & $\begin{array}{l}\text { HART, } \\
\mathrm{O}\end{array}$ & 7.23 & -69 . & & 0.049 & 4,5 & 0.11 & as Pole & \\
\hline 6 & $\begin{array}{r}\text { This work } \\
\text { NK }\end{array}$ & $\begin{array}{l}\text { k: GOUG } \\
\text { xLG, SUT }\end{array}$ & $\begin{array}{l}\text { HART, } \\
\text { I }\end{array}$ & -21.76 & -5 . & & 0.099 & 4,5 & 1.80 & as Pole & \\
\hline
\end{tabular}

ancy in the Mediterranean area, we make some considerations about the uncertainties that might affect the presently available geodetic data in that region. The main source of uncertainty may come from the fact that only few GPS permanent stations are currently operating in
Nubia (fig. 5 and table IIIa) and that most of them are located along active deforming boundaries of this plate (figs. 1, 2 and 5), as also recognized by Altamimi et al. (2002) and Sella et al. (2002). The station of MASP (Mas Palomas, Gran Canaria Island, indicated in literature 
as MAS and MAS1 also) is located along an active tectonic belt affected by volcanic and seismic activity, Miocene to Quaternary giant landslides and considerable (about $1 \mathrm{~cm} / \mathrm{yr}$ ) vertical and horizontal ground motion (e.g., Mezcua et al., 1992; Carracedo et al., 1999; Anguita and Hernan, 2000; Fernandez et al., 2003; Gonzalez de Vallejo et al., 2003). The station of GOUG lies very close to the South Atlantic spreading ridge. The station of NKLG (Libreville, Gabon), is located near the Cameroon line, where recent tectonic and volcanic activity is recognized (e.g., Suleiman et al., 1993; Ateba and Ntepe, 1997; Ubangoh et al., 1997; Foster and Jackson, 1998). No recent seismotectonic activity is instead recognized in the zone where the stations of the South African Hartebeesthoek Observatory (HAR, HARB, HARK, HRAO and HART) are located. One should also consider that most African stations (all but HRAO and MASP) have been excluded from the network of core sites used for defining the ITRF2000 solution since they do not satisfy quality criteria adopted for site selection (Altamimi et al., 2002).

In order to check the stability of the NubiaEurasia Euler poles with respect to the set of stations considered, we have carried out some experiments. The Nubia-Eurasia Euler poles obtained by such experiments (poles 4, 5 and 6, given in table IIIb and illustrated in fig. 5) are computed as the difference between the related Nubia and Eurasia absolute Euler poles, obtained by inverting sets of absolute geodetic velocities in a weighted least-squares approach which minimizes the parameter $\chi^{2}$ (e.g., DeMets et al., 1990). For each Euler pole, the goodness of fit is measured by the reduced $\chi^{2}$ error $\left(\chi_{v}^{2}=\chi^{2} / v\right)$ where $v$ is the number of degrees of freedom, depending on the number of stations used in the inversion (e.g., Kreemer et al., 2003). For the computation of poles 4, 5 and 6 we have adopted the Eurasia absolute pole provided by Prawirodirdjo and Bock (2004). The NubiaEurasia Euler poles taken from literature (cases 1 to 3 in table IIIb) derive from Nubia and Eurasia absolute poles for which complete information about $\chi_{v}{ }^{2}$ parameters is available.

The results given in table IIIb and fig. 5 raise doubts about the constraining power of the presently available data set in the Nubia plate, since the parameters of Euler poles show a strong dependence on the set of stations considered. In particular, it can be noted that the poles computed without taking MASP into account are characterized by locations and angular velocities considerably different from those of the first three poles and that including the station NKLG in the data set (pole 6 in table IIIb) provides a particularly bad fit.

At last, it is worth noting that the kinematics predicted by the Euler poles 4 and 5 (obtained without using MASP and NKLG) in the Southern Adriatic is fairly compatible with the geodetic velocity of MATE (fig. 5). This evidence, and the fact that the $\chi_{v}^{2}$ values related to poles 4 and 5 are much lower than those of poles 1, 2 and 3 (table IIIb) may imply that geodetic data could be reconciled with the NubiaEurasia kinematics suggested by Mediterranean evidence if the most uncertain geodetic vectors, as MASP and NKLG, are not considered. However, since recognizing the actual quality and geodynamic significance of geodetic data is not so simple, we believe that any attempt to derive Euler poles from the presently available data set in Nubia (defined as «geodetically poor» by Altamimi et al., 2002) should be considered with caution.

\section{Conclusions}

We argue that current ideas on the recent (last few Myr) relative motion between Nubia and Eurasia, generally based on the analysis of North Atlantic data (e.g., the NUVEL-1 model), might be not reliable. This hypothesis is suggested by the analysis of the Plio-Quaternary deformation pattern in the Mediterranean region, which coherently indicate a NNE ward Nubia-Eurasia convergence, rather different from the NNW ward convergence trend provided by the NUVEL-1 model. The possibility that NUVEL-1 Nubia-Eurasia kinematics is not reliable is also suggested by the fact that the twoplates configuration adopted by such approach cannot explain the occurrence of significant seismotectonic activity in some zones lying inside the presumed Nubia and Eurasia plates, 
such as Pyrenees, Portugal and the Transmoroccan-Canary fault system. In this paper it is shown that if a more reliable plate configuration, involving the Iberia and Morocco intervening microplates, is adopted, a kinematic pattern can be identified which accounts, within the respective errors, for both Mediterranean and North Atlantic (NUVEL-1) constraints.

Understanding why the Nubia-Eurasia convergence trend indicated by Mediterranean evidence is significantly different from the one inferred by geodetic data is not a simple task. In our opinion, the present network of permanent GPS stations in Africa may be still inadequate to determine Nubia's kinematics. The main problem is that no or very few stations are available in the stable part of Africa. In addition, the Nubia-Eurasia Euler poles so far proposed in the literature are considerably influenced by the set of stations considered. In particular, such poles are strongly conditioned by the use of the site (MASP) located at the Canary Island active tectonic belt, which is recognized as a possible westward prosecution of the Transmoroccan fracture zone. To explain the discrepancy between the Nubia-Eurasia kinematic models obtained by different approaches, one should also consider the possibility that the Mediterranean constraints we take into account are not as significant as we claim. However we think this is unlikely, since our point of view is supported by the major features we describe in this work and can also provide plausible and coherent explanations for the Mediterranean deformation pattern inferred from a large amount of geological, geophysical and volcanological evidence (Mantovani et al., 1997, 2002, 2006a; Mantovani, 2005). Thus, we think that any conclusion about the reliability of the Nubia-Eurasia kinematics deduced by Mediterranean features should be drawn only after having considered the complete framework of evidence and arguments in support of that interpretation.

On the other hand, we think that any attempt to defend the reliability of the Nubia-Eurasia kinematics provided by the NUVEL-1 model or inferred from geodetic data should be accompanied by plausible explanations of how the major problems we raise in this work can be overcome. For instance, it does not seem scientifi- cally opportune using a Nubia-Eurasia kinematic model which predicts no deformation in zones affected by strong seismicity, needs a decoupling between Adria and Nubia not documented by any significant evidence, and cannot provide any plausible explanation for the morphology and tectonic setting of the Cyprus Arc and for the sinistral shear observed at the Transmoroccan fault system and for many other features (e.g., Mantovani, 2005).

\section{Acknowledgements}

We are grateful to Prof. Paolo Baldi and Dr. Andrea Argnani for their valuable suggestions, which allowed a significant improvement of the work. The research has been financially supported by the Italian Ministry of Research (PRIN) and University of Siena (PAR).

\section{REFERENCES}

Ait Brahim, L., P. Chotin, S. Hinaj, A. Abdelouafi, A. El Adraoui, C. Nakcha, D. Dhont, M. Charroud, F. Sossey Alaoui, M. Amrhar, A. Bouaza, H. TabaYAOUI and A. ChaOUni (2002): Paleostress evolution in the Moroccan African margin from Triassic to Present, Tectonophysics, 357, 187-205.

Ait Brahim, L., B. Tadili, I. Mounyn, M. Ramdani, M. Limouri, A. El QAdi, F. Sossey Alaoui and M. BenHALIMA (2004): Using active faults and seismicity for the strong motion modeling in the Eastern Rif (Northern Morocco), Pure Appl. Geophys., 161, 1081-1091.

Aksu, A.E., J. Hall and C. YaltiRaK (2005): Miocene to Recent tectonic evolution of the Eastern Mediterranean: new pieces of the old Mediterranean puzzle, Mar. Geol., 221, 1-13.

Alasset, P.-J. and M. Meghraoui (2005): Active faulting in the Western Pyrénées (France): paleoseismic evidence for late Holocene ruptures, Tectonophysics, 409, 39-54.

Alfaro, P., J. Delgado, A. Estévez, J.M. Soria and A. YÉBENES (2002): Onshore and offshore compressional tectonics in the eastern Betic Cordillera (SE Spain), Mar. Geol., 186, 337-349.

AltAMimi, Z., P. SiLlard and C. Boucher (2002): ITRF2000: a new release of the International Terrestrial Reference Frame for Earth science applications, J. Geophys. Res., 107, ETG 2.

ANDERSON, H. and J. JACKSON (1987): Active tectonics of the Adriatic region, Geophys. J.R. Astron. Soc., 91, 937-983.

AndeweG, B. and S. Cloetingh (2001): Evidence for an active sinistral shear zone in the western Alboran region, Terra Nova, 13, 44-50.

Angelier, J., N. Lyberis, X. Le Pichon, E. BARrier and P. 
HuchON (1982): The tectonic development of the Hellenic Arc and the Sea of Crete: a synthesis, Tectonophysics, 86, 159-196.

ANGUITA, F. and F. HERNÀN (1975): A propagating fracture model versus a hot spot origin for the Canary Islands, Earth Planet. Sci. Lett., 27, 11-19.

Anguita, F. and F. HERnÀn (2000): The Canary Islands origin: a unifying model, J. Volcanol. Geotherm. Res., 103, $1-26$.

ARgnANI, A. (2006): Some issues regarding the Central Mediterranean neotectonics, Boll. Geofis. Teor. Appl., 47, 13-37.

Argnani, A. and C. Bonazzi (2005): The Malta Escarpment fault zone offshore Sicily: Pliocene-Quaternary tectonic evolution based on new multichannel seismic data, Tectonics, 24, TC4009.

ARgnANI, A. and F. Frugoni (1997): Foreland deformation in the Central Adriatic and its bearing on the evolution of the Northern Apennines, Ann. Geofis., XL (3), 771-780.

Argnani, A., F. Frugoni, R. Cosi, M. Ligi and P. Favali (2001): Tectonics and seismicity of the Apulian Ridge south of the Salento Peninsula (Southern Italy), Ann. Geofis., 44 (3), 527-540.

Argus, D.F., R.G. Gordon, C. DeMets and S. Stein (1989): Closure of the Africa-Eurasia-North America plate circuit and tectonics of the Gloria Fault, J. Geophys. Res., 94, 5585-5602.

Armijo, R., B. Meyer, A. Hubert and A. Barka (1999): Westward propagation of the North Anatolian fault into the Northern Aegean: timing and kinematics, Geology, 27, 267-270.

ArmiJo, R., F. Flerit, G. King and B. Meyer (2003): Linear elastic fracture mechanics explains the past and present evolution of the Aegean, Earth Planet. Sci. Lett., 217, 85-95.

AtEBA, B. and N. NTEPE (1997): Post-eruptive seismic activity of Mount Cameroon (Cameroon), West Africa: a statistical analysis, J. Volcanol. Geotherm. Res., 79, 25-45.

Babbucci, D., C. Tamburelli, M. Viti, E. Mantovani, D. Albarello, F. D'Onza, N. Cenni and E. Mugnaioli (2004): Relative motion of the Adriatic with respect to the confining plates: seismological and geodetic constraints, Geophys. J. Int., 159, 765-775.

Banda, E., C.R. Ranero, J.J. Danobeitia and A. Riviero (1992): Seismic boundaries of the eastern central Atlantic Mesozoic crust from multichannel seismic data, Geol. Soc. Am. Bull., 104, 1340-1349.

Bargach, K., P. Ruano, A. Chabli, J. Galindo-Zaldivar, A. Chalouan, A. Jabaloy, M. Akil, M. Ahmamou, C. SANZ DE GaldeAno and M. BenMaKhlouf (2004): Recent tectonic deformations and stresses in the frontal part of the rif Cordillera and the Saiss Basin (Fes and Rabat regions, Morocco), Pure Appl. Geophys., 161, 521-540.

BArKA, A.A. (1992): The North Anatolian fault zone, Ann. Tectonicae, 6, 164-195.

BARKA, A.A. (1996): Slip distribution along the North Atlantic fault associated with the large earthquakes of the period 1939 to 1967, Bull. Seismol. Soc. Am., 86, 12381254.

Battaglia, M., M.H. Murray, E. Serpelloni and R. BuRGMANN (2004): The Adriatic region: an independent microplate within the Africa-Eurasia collision zone, Geophys. Res. Lett., 31, L09605.
Beauchamp, W., R.W. Allmendinger, M. Barazangi, A. Demnati, M. El AlJi and M. DAHMANi (1999): Inversion tectonics and the evolution of the High Atlas Mountains, Morocco, based on a geological-geophysical transect, Tectonics, 18, 163-184.

Bernini, M., M. Boccaletti, G. Moratti and G. PaPani (2000): Structural development of the Taza-Guercin Basin as a constraint for the Middle Atlas Shear Zone tectonic evolution, Mar. Petrol. Geol., 17, 391-408.

Borges, J.F., A.J.S. Fitas, M. Bezzeghoud and P. TevesCosta (2001): Seismotectonics of Portugal and its adjacent Atlantic area, Tectonophysics, 337, 373-387.

BREDE, R. (1992): Structual aspects of the Middle and the High Atlas (Morocco) phenomena and causalities, $\mathrm{Ge}$ ol. Rund., 81, 171-184.

Brede, R., M. Hauptmann and H.-G. Herbig (1992): Plate tectonics and interaction mountain ranges in Morocco The Mesozoic-Cenozoic development of the Central High Atlas and the Middle Atlas, Geol. Rund., 81, $127-$ 141 .

Buforn, E., A. Udias and M.A. Colombas (1988): Seismicity, source mechanism and tectonics of the AzoresGibraltar plate boundary, Tectonophysics, 152, 89-118.

Buforn, E., C. Sanz de Galdeano and A. Udias (1995): Seismotectonics of the Ibero-Maghrebian Region, Tectonophysics, 248, 247-261.

Buforn, E., M. Bezzeghoud, A. Udias and C. Pro (2004): Seismic sources on the Iberia-Africa plate boundary and their tectonic implications, Pure Appl. Geophys. 161, 623-646.

CABRAL, J. (1989): An example of intraplate neotectonic activity, Vilarica Basin, northeast Portugal, Tectonics, 8 , 285-303.

Calais, E., D. DeMets and J.-M. Nocquet (2003): Evidence for a post-3.16 Ma change in Nubia-EurasiaNorth America plate motions?, Earth Planet. Sci. Lett., 216, 81-92.

Carracedo, J.C., S.J. Day, H. Guillon and F.J. Pérez TORRADO (1999): Giant Quaternary landslides in the evolution of La Palma and El Hierro, Canary Islands, $J$. Volcanol. Geotherm. Res., 94, 169-190.

Cenni, N., F. D'Onza, M. Viti, E. Mantovani, D. AlbarelLO and D. BABBUCCI (2002): Post seismic relaxation processes in the Aegean-Anatolian system: insights from space geodetic data (GPS) and geological/geophysical evidence, Boll. Geofis. Teor. Appl., 43, 23-36.

Cetin, H., H. Guneyli and L. MAYer (2003): Paleoseismology of the Palu-Lake Hazar segment of the east Anatolian fault zone, Turkey, Tectonophysics, 374, 163-197.

Chaumillon, E. and J. Mascle (1997): From foreland to forearc domains: new multichannel seismic reflection survey of the Mediterranean ridge accretionary complex (Eastern Mediterranean), Mar. Geol., 138, 237-259.

Chu, D. and R.G. Gordon (1998): Current plate motions across the Red Sea, Geophys. J. Int., 135, 313-328.

Console, R., R. Di Giovambattista, P. Favali, B.W. PresGRAVE and G. SMriglio (1993): Seismicity of the Adriatic microplate, Tectonophysics, 218, 343-354.

DAY, S.J., J.C. CoRracedo, H. Guillou and P. Gravestock (1999): Recent structural evolution of the Cumbre Vieja volcano, La Palma, Canary islands: volcanic rift zone reconfiguration as a precursor to volcano flank instability?, J. Volcanol. Geotherm. Res., 94, 135-167. 
Deffontaines, B., P. Chotin, L. Ait Brahim and M. RozaNOV (1992): Investigation of active faults in Morocco using morphometric methods and drainage pattern analysis, Geol. Rund., 81, 199-210.

DeMets, C., R.G. Gordon, D.F. Argus and S. Stein (1990): Current plate motions, Geophys. J., 101, 425-478.

DeMets, C., R.G. Gordon, D.F. Argus and S. Stein (1994): Effect of recent revisions to the geomagnetic reversal time scale on estimates of current plate motions, Geophys. Res. Lett., 21, 2191-2194.

Dercourt, J., L.P. Zonenshain, L.E. Ricou, V.G. KAZMin, X. Le Pichon, A.L. KnipPer, C. GrandjacQuet, I.M. Sbortshikov, J. Geyssant, C. LePVRIRER, D.H. PECHERSKY, J. Boulin, J.C. Sibuet, L.A. Savostin, O. SoroKHTIN, M. WESTPHAL, M.L. BAZChENOV, J.P. LAUER and B. Biju-Duval (1986): Geological evolution of the Tethys belt from Atlantic to the Pamirs since the Lias, in Evolution of the Tethys, edited by J. AuBOuIN, X. LE PICHON and A.S. MonIN, Tectonophysics, 123, 241-315.

DeZES, P., S.M. SCHMID and P.A. ZIEGLER (2004): Evolution of the European Cenozoic Rift System: interaction of the Alpine and Pyrenean orogens with their foreland lithosphere, Tectonophysics, 389, 1-33.

Dewey, J.F. and A.M.C. SENGor (1979): Aegean and surrounding regions: complex multiplate and continuum tectonics in a convergent zone, Geol. Soc. Am. Bull., 90, 89-92.

Dewey, J.F., M.L. Helman, E. Turco, D.H.W. Hutton and S.D. KNOTT (1989): Kinematics of the Western Mediterranean, in Alpine Tectonics, edited by M.P. CowARD, D. DieTrich and R.G. PARK, Geol. Soc. London Spec. Publ. $45,265-283$

Dhont, D., J. Chorowicz, T. YÜrür and O. Kose (1998): Polyphased block tectonics along the North Anatolian Fault in the Tosya Basin area (Turkey), Tectonophysics, 299, 213-227.

El Alami, S.O., B. Tadili, L. Ait Brahim and I. Mouyan (2004): Seismicity of Morocco for the period 19871994, Pure Appl. Geophys., 161, 969-982.

El AzzaB, D. and M. El Wartiti (1998): Paléomagnétisme des levels du Moyen Atlas (Maroc): rotations récentes, Earth Planet. Sci. Lett, 327, 509-512.

El Azzouzi, M., J. Bernard-Griffiths, H. Bellon, R.C. Maury, A. Piqué, S. Fourcade, J. Cotton and J. HerNANDEZ (1999): Evolution des sources du volcanisme marocain au cours du Néogène, Earth Planet. Sci. Lett., 329, 95-102.

FAulKNeR, D.R., A.C. Lewis and E.H. RutTER (2003): On the internal structure and mechanics of large strike-slip fault zones: field observations of the Carboneras Fault in southeastern Spain, Tectonophysics, 367, 235-251.

Favali, P., R. Funiciello, G. Mattietti, G. Mele and F. SALVINI (1993): An active margin across the Adriatic Sea (Central Mediterranean Sea), Tectonophysics, 219, 109-117.

FÉraud, G., G. Giannérini, R. CAMpredon and C.J. StillMAN (1985): Geochronology of some Canarian dike swarms: contribution to the volcano-tectonic evolution of the archipelago, J. Volcanol. Geotherm. Res., 25, 29-52.

FERnÀndeZ, J., T.-T. Yu, G. RodrìgueZ-Velasco, J. GonzÀlez-Matesanz, R. Romero, G. Rodrìguez, R. Quiros, A. DAlda, A. Aparico and M.J. Blanco (2003): New geodetic monitoring system in the vol- canic island of Tenerife, Canaries, Spain. Combination of InSAR and GPS techniques, J. Volcanol. Geotherm. Res., 124, 241-253.

FINETTI, I.R. (Editor) (2005): Deep Seismic Exploration of the Central Mediterranean and Italy, CROP Project (Elsevier, Amsterdam), pp. 794.

FOSTER, A.N. and J.A. JACKSON (1998): Source parameters of large African earthquakes: implications for crustal rheology and regional kinematics, Geophys. J. Int., 134, 422-448.

Fournier, M., P. PATriat and S. Leroy (2001): Reappraisal of the Arabia-India-Somalia triple junction kinematics, Earth Planet. Sci. Lett., 189, 103-114.

Fullea, J., M. FernàndeZ, H. ZeYen and J. Vergés (2007): A rapid method to map the crustal and lithospheric thickness using elevation, geoid anomaly and thermal analysis. Application to the Gibraltar Arc System, Atlas Mountains and adjacent zones, Tectonophysics, 430, 97-117.

Galindo-Zaldivar, J., L.M. NiETO, A.H.F. RoberTSON and J.M. Woodside (2001): Recent tectonics of Eratosthenes Seamount: an example of seamount deformation during incipient continental collision, Geo-Mar. Lett., 20, 233-242.

Gomez, F., M. Barazangi and M. Bensaid (1996): Active tectonism in the intracontinental Middle Atlas Mountains of Morocco: synchronous crustal shortening and extension, J. Geol. Soc. London, 153, 389-402.

Gomez, F., R. Allmendinger and M. BARAZANGi (1998): Crustal shortening and vertical strain partitioning in the Middle Atlas Mountains of Morocco, Tectonics, 17, 520-533.

Gomez, F., M. Meghraoui, A.N. Darkal, F. Hijazi, M. Mouty, Y. Suleiman, R. Sbeinati, R. Darawchec, R. AL-GHAZZI and M. BARAZANGI (2003): Holocene faulting and earthquake recurrence along the Serghaya branch of the Dead Sea fault system in Syria and Lebanon, Geophys. J. Int., 153, 658-674.

Gomez, F., M. Khawlie, C. Tabet, A.N. Darkal, K. Khair and M. BARAZANGi (2006): Late Cenozoic uplift along the Northern Dead Sea transform in Lebanon and Syria, Earth Planet. Sci. Lett., 241, 913-931.

Gonzalez de Vallejo, L.I., R. CAPote, L. Cabrera, J.M. InsUA and J. ACOSTA (2003): Paleoearthquake evidence in Teneriffe (Canary Islands) and possible seismotectonic sources, Mar. Geophys. Res., 24, 149-160.

Gordon, R.G. (1995): Plate motions, crustal and lithospheric mobility, and paleomagnetism: prospective viewpoint, J. Geophys. Res., 100, 24367-24392.

Goula, X., C. Olivera, J. Fleta, B. Grellet, R. Lindo, L.A. Rivera, A. Cisternas and D. Carbon (1999): Present and recent stress regime in the eastern part of the Pyrenees, Tectonophysics, 308, 487-502.

Gràcia, E., R. Pallàs, J.I. Soto, M. Comas, X. Moreno, E. Msana, P. Santanach, S. Diez, M. Garcia and J. DANOBEITIA (2006): Active faulting offshore SE Spain (Alboran Sea): implications for earthquake hazard assessment in the Southern Iberian margin, Earth Planet. Sci. Lett., 241, 734-749.

Grellet, B., Ph. Combes, Th. Granier and H. PhiliP (1993): Sismotectonique de la France Métropolitaine, Mem. Soc. Geol. Fr., 164, pp. 76.

Gutscher, M.-A., M.-A. BAPtista and J.M. MirandA (2006): The Gibraltar Arc seismogenic zone, Part 2. Con- 
straints on a shallow east dipping fault plane source for the 1755 Lisbon earthquake provided by tsunami modeling and seismic intensity, Tectonophysics, 426, 153-166.

Hall, J., A.E. Aksu, T.J. Calon and D. Yasar (2005a): Varying tectonic control on basin development at an active microplate margin: Latakia Basin, Eastern Mediterranean, Mar. Geol., 221, 15-60.

Hall, J., T.J. Calon, A.E Aksu and S.R. Meade (2005b): Structural evolution of the Latakia Ridge and Cyprus Basin at the front of the Cyprus Arc, Eastern Mediterranean Sea, Mar. Geol., 221, 261-297.

HARMAND, C. and A. MouKADIRI (1986): Synchronisme entre tectonique compressive ed volcanisme alcalin: example de la province quaternarie du Moyen Atlas (Maroc), Bull. Soc. Géol. Fr., 8, 595-603.

HatzFeld, D., V. Caillot, T.E. Cherkaoui, H. Jebli and F. Medina (1993): Microearthquake seismicity and fault plane solutions around the Nékor strike-slip fault, Morocco, Earth Planet. Sci. Lett., 120, 31-41.

Hayward, N., A. Watts, G. Westbrook and J. Collier (1999): A seismic reflection and GLORIA study of compressional deformation in the Gorringe Bank region, eastern North Atlantic, Geophys. J. Int., 138, 831-850.

Hempton, M.R. (1987): Constraints on Arabian plate motion and extensional history of the Red Sea, Tectonics, 6, 687-705.

Herraiz, M., G. De Vicente, R. Lindo-Naupari, J. Giner, J.L. Simon, J.M. GonZÀlez-Casado, O. Vadillo, M.A. Rodriguez-Pascua, J.I. CicuÉndez, A. CASAs, L. Cabanas, P. Rincon, A.L. Cortés, M. Ramirez and M. LuCINI (2000): The recent (Upper Miocene to Quaternary) and present tectonic stress distribution in the Iberian peninsula, Tectonics, 19, 762-786.

Hinzen, K.G. (2003): Stress field in the Northern Rhine area, Central Europe, from earthquake fault plane solutions, Tectonophysics, 377, 325-356.

Hubert-Ferrari, A., R. Armijo, G. King, B. Meyer and A. BARKA (2002): Morphology, displacement, and slip rates along the North Anatolian Fault, Turkey, J. Geophys. Res., 107, ETG 9, 1-33, doi: 10.1029/2001JB000393.

JaBAlOY, A., J. Galindo-Zaldìvar and F. GonZÀleZ-LoDEIRO (2002): Palaeostress evolution of the Iberian Peninsula (Late Carboniferous to present-day), Tectonophysics, 357, 159-186.

JACOBSHAGEN, V. (1992): Major fracture zones of Morocco: the South Atlas and the Transalboran fault systems, $\mathrm{Ge}$ ol. Rund., 81, 185-197.

Kahle, H.-G., M. Cocard, P. Yannick, A. Geiger, R. REILINGER, A. BARKA and G. VeIs (2000): GPS-derived strain rate field within the boundary zones of the Eurasian, African and Arabian Plates, J. Geophys. Res., 105, 23353-23370.

KEMPLER, D. and Z. GARFunKEL (1994): Structures and kinematics in the northeastern Mediterranean: a study of an irregular plate boundary, Tectonophysics, 234, 19-32.

Kiratzi, A.A. and C.B. PAPAZACHOS (1995): Active crustal deformation from the Azores triple junction to the Middle East, Tectonophysics, 243, 1-24.

Klinger, Y., J.P. Avouac, N. Abou Karaki, L. Dorbath, D. Bourles and J.L. ReYsS (2000a): Slip rate on the Dead Sea transform fault in Northern Araba Valley (Jordan), Geophys. J. Int., 142, 755-768.

Klinger, Y., J.P. Avouac, L. Dorbath, N. Abou Karaki and N. TiSnerat (2000b): Seismic behavior of the Dead Sea along Araba valley Jordan, Geophys. J. Int., 142, 769-782.

KreEMER, C., W.E. Holt and A.J. HAines (2003): An integrated global model of present-day plate motions and plate boundary deformation, Geophys. J. Int., 154, 8-34.

Le PiCHON, X. and J. Angelier (1979): The Hellenic Arc and trench system: a key to the neotectonic evolution of the Eastern Mediterranean area, Tectonophysics, 60, 1-42.

Le Pichon, X., P. Huchon, J. Angelier, N. Lyberis, J. Boulin, D. Bureau, J.-P. Cadet, J. Dercourt, G. Glaçon, H. Got, D. Karig, J. Mascle, L.-E. Ricou and F. ThiÉBAult (1981): Active tectonics in the Hellenic trench, Oceanologica Acta, SP4, 273-282.

Li, X., G. Bock, A.Vafidis, R. Kind, H.-P. HarJes, W. Hanka, K. Wylegalla, M. van der Meidde and X. YUAN (2003): Receiver function study of the Hellenic subduction zone: imaging crustal thickness variations and the oceanic Moho of the descending African lithosphere, Geophys. J. Int., 155, 733-748.

Lopez-Casado, C., C. Sanz de Galdeano, S. Molina PalaCIOS and J. HENARES ROMERO (2001): The structure of the Alboran Sea: an interpretation from seismological and geological data, Tectonophysics, 338, 79-95.

LYNNES, C.S. and L.J. RUFF (1985): Source process and tectonic implications of the great 1975 North Atlantic earthquake, Geophys. J. R. Astron. Soc., 82, 497-510.

Maldonado, A., L. Somoza and L. Pallarés (1999): The Betic orogen and the Iberian-African boundary in the Gulf of Cadiz: geological evolution (central north Atlantic), Mar. Geol., 155, 9-43.

Mantovani, E. (2005): Evolutionary reconstruction of the Mediterranean region: extrusion tectonics driven by plate convergence, in Deep Seismic Exploration of the Mediterranean Region, CROP Project, edited by I.R. FinetTI (Elsevier, Amserdam), Chap. 32, 705-746.

Mantovani, E., D. Albarello, C. TAmburelli, D. BabBucCI and M. VITI (1997): Plate convergence, crustal delamination, extrusion tectonics and minimization of shortening work as main controlling factors of the recent Mediterranean deformation pattern, Ann. Geofis., XL (3), 611643.

Mantovani, E., M. Viti, D. Babbucci, C. TAmburelli and D. Albarello (2001a): Back Arc extension: which driving mechanism?, J. Virtual Explorer, 3, 17-44.

Mantovani, E., M. Viti, N. Cenni, D. Albarello and D. BABBUCCI (2001b): Short and long-term deformation patterns in the Aegean-Anatolian systems: insights from space geodetic data (GPS), Geophys. Res. Lett., 28, 2325-2328.

Mantovani, E., N. Cenni, D. Albarello, M. Viti, D. BabBuCCI, C. TAMBurelli and F. D'OnZa (2001c): Numerical simulation of the observed strain field in the central-eastern Mediterranean region, J. Geodynamics, 31, 519-556.

Mantovani, E., D. Albarello, D. Babbucci, C. TambuRELLI and M. VITI (2002): Trench-Arc-Back-Arc systems in the Mediterranean area: examples of extrusion tectonics, J. Virtual Explorer, 8, 125-141.

Mantovani, E., M. Viti, D. BabBucci, C. TAmburelli and D. Albarello (2006a): Geodynamic correlation between the indentation of Arabia and the Neogene tectonics of the central-eastern Mediterranean region, in 
Post-Collisional Tectonics and Magmatism in the Eastern Mediterranean Region, edited by Y. DILEK and S. Pavlides, Geol. Soc. Am. Spec. Pap. 409, 15-41.

Mantovani, E., D. Babbucci, M. Viti, D. Albarello, E. Mugnaioli, N. Cenni, and G. Casula (2006b): PostLate Miocene kinematics of the Adria microplate: inferences from geological, geophysical and geodetic data, in The Adria Microplate: GPS Geodesy, Tectonics, and Hazards, edited by N. PINTER (Springer, The Netherlands), 51-69.

MARINONI, L.B. (2001): Crustal extension from exposed sheet intrusions: review and method proposal, J. Volcanol. Geotherm. Res., 107, 27-46.

Marrett, R. and R.W. Allmendinger (1990): Kinematic analysis of fault slip data, J. Struct. Geol., 12, 973-986.

Martinez-Diaz, J.J., T. Capote, M. Tsige, P. Villamor, F. Martin-GonZalez and J.M. Insua-AREVAldo (2006): Seismic triggering in a stable continental area: the Lugo 1995-1997 seismic sequences (NW Spain), J. Geodyn., 41, 440-449.

Martinez-Martinez, J.M., G. Booth-Rea, J.M. Azanon and F. TORCAL (2006): Active transfer fault zone linking a segmented extensional system (Betics, Southern Spain): insight into heterogeneous extension driven by edge delamination, Tectonophysics, 422, 159-173.

Mascle, J. and P. Chaumillon (1997): Pre-collisional geodynamics of the Mediterranean Ridge and the Tyrrhenian Sea, Ann. Geofis., XL (3), 569-586.

Mauffret, A., B. Durand de Grossouvre, A. Tadeu Dos ReIS, C. GorinI and A. NERCESSIAN (2001): Structural geometry in the Eastern Pyrenees and Western Gulf of Lion (Western Mediterranean), J. Struct. Geol., 23, 17011726.

Mazabraud, Y., N. Béthoux, J. Guilbert and O. Bellier (2005): Evidence for short scale stress field variations within intraplate central-western France, Geophys. J. Int., 160, 161-178.

McClusky, S., S. Balassanian, A. Barka, C. Demir, S. Ergintav, I. Georgiev, O. Gurkan, M. Hamburger, K. Hurst, H. Khale, K. Kastens, G. KeKelidze, R. King, V. Kotzev, O. LenK, S. Mahmoud, A. Mishin, M. NadARIYA, A. OuZOunis, D. PARAdissis, Y. PETER, M. Prilepin, R. Reilinger, I. Sanli, H. Seeger, A. Tealeb, M.N. ToKsÖZ and G. VEIS (2000): Global positioning system constraints on plate kinematics and dynamics in the Eastern Mediterranean and Caucasus, J. Geophys. Res., 105, 5695-5719.

McClusky, S., R. Reilinger, S. Mahmoud, D. Ben SARi and A. TEAleb (2003): GPS constraints on Africa (Nubia) and Arabia plate motion, Geophys. J. Int., 155, 126-138.

McKenzIE, D. (1978): Active tectonics of the Alpine-Himalayan belt: the Aegean Sea and sourrounding region, Geophys. J. R. Astron. Soc., 55, 217-254.

Medialdea, T., R. Vegas, L. Somoza, J.T. Vasquez, A. Maldonado, V. Diaz-Del-Rio, A. Maestro, D. CoRDOBA and M.C. FERnANDEZ-PugA (2004): Structure and evolution of the «Olistostrome» complex of the Gibraltar Arc in the Gulf of Cadiz (eastern central Atlantic): evidence from two long seismic cross-sections, Mar. Geol., 209, 173-198.

MedinA, F. (1995): Present-day state of stress in Northern Morocco from focal mechanism analysis, J. Struct. Geol., 17, 1035-1046.
Medina, F. and T.E. Cherkaoui (1991): Focal mechanisms of the Atlas earthquakes, and tectonic implications, $G e$ ol. Rund., 80, 639-648.

Meghraoui, M. and F. Doumaz (1996): Earthquake-induced flooding and paleoseismicity of the El Asnam, Algeria, fault-related fold, J. Geophys. Res., 101, 17617-17644.

Meghraoui, M., A. Cisternas and H. Philip (1986): Seismotectonics of the lower Cheliff Basin: structural background of the El Asnam (Algeria) earthquake, Tectonics, 5, 809-836.

Meghraoui, M., J.-L. Morel, J. Andreaux and M. DahMANI (1996): Tectonique plio-quaternaire de la chaîne tello-rifaine et de la mer d'Alboran. Une zone complexe de convergence continent-continent, Bull. Soc. Géol. France, 167, 141-157.

Mezcua, J., E. Buforn, A. Udias and J. Rueda (1992): Seismotectonics of the Canary Islands, Tectonophysics, 203, 447-452.

Minster, B.J. and T.H. Jordan (1978): Present day plate motions, J. Geophys. Res., 83, 5331-5354.

Moratti, G., L. Piccardi, G. Vannucci, M.E. Belardinelli, M. DAhMani, A. BendKiK and M. Chenakeb (2003): The 1755 «Meknes» earthquake (Moroccco): field data and geodynamic implications, J. Geodyn., 36, 305-322.

Morel, J.L. and M. Meghraoui (1996): Gorringe-AlboranTell tectonic zone: a transpression system along the Africa-Eurasia plate boundary, Geology, 8, 755-758.

Mustaphi, H., F. Medina, H. Jabour and C. HoepfFner (1997): Le bassin du Souss (zone de Faille du Tizi n'Test, Haut Atlas occidental, Maroc): résultat d'une inversion tectonique controlée par une faille de détachement profonde, J. Afr. Earth Sci., 24, 153-168.

NiviÈRE, B. and T. WINTER (2000): Pleistocene northwards fold propagation of the Jura within the southern Upper Rhine Graben: seismotectonic implications, Global Planet. Change, 27, 263-288.

NocQuet, J.-M. and E. CALAIS (2004): Geodetic Measurements of Crustal Deformation in the Western Mediterranean and Europe, Pure Appl. Geophys., 161, 661-681.

Nyst, M. and W. Thatcher (2004): New constraints on the active deformation of the Aegean, J. Geophys. Res., 109, B11406, 1-23.

Oldow, J.S., L. Ferranti, D.S. Lewis, J.K. Campbell, B. D'Argenio, R. Catalano, G. Pappone, L. CarmignaNI, P. Conti and C.L.V. Aiken (2002): Active fragmentation of Adria, the North African promontory, Central Mediterranean orogen, Geol. Soc. Am., 9, 779-782.

PApazachos, B.C. and CH.A. PAPAIOANNOU (1999): Lithospheric boundaries and plate motions in the Cyprus area, Tectonophysics, 308, 193-204.

Pauchet, H., A. Rigo, L. Rivera and A. Souriau (1999): A detailed analysis of the February 1996 aftershock sequence in the Eastern Pyrenees, France, Geophys. J. Int., 137, 107-127.

Persaud, M. and O.A. PfifFNer (2004): Active deformation in the eastern Swiss Alps: post-glacial faults, seismicity and surface uplift, Tectonophysics, 385, 59-84.

PIPER, D.J.W. and C. PERISSORATIS (2003): Quaternary neotectonics of the South Aegean Arc, Mar. Geol., 198, 259-288.

Piper, J.D.A., O. Tatar, H. Gursoy, F. Kocbulut and B.L. Mesci (2006): Paleomagnetic analysis of neotectonic deformation in the Anatolian accretionary collage, 
Turkey, in Postcollisional tectonics and magmatism in the Mediterranean region and Asia, edited by Y. DILEK and S. Pavlides, Geol. Soc. Am. Spec. Pap. 409, 417439.

Piqué, A., L. Ait Brahim, M. El Azzouzi, R.C. Maury, H. Bellon, B. Semroud and E. Laville (1998): Le poinçon maghrébin: contraintes structurales et géochimiques, Earth Planet. Sci. Lett., 326, 575-581.

Plenefisch, T. and K.P. BonJer (1997): The stress field in the Rhine Graben area inferred from earthquake focal mechanism and estimation of frictional parameters, Tectonophysics, 275, 71-97.

Polonia, A., L. Gasperini, A. Amorosi, E. Bonatti, G. BortoluzZi, N. Çatagay, L. Capotondi, M.H. Cormier, N. GÖRÜR, C. McHugh and L. SEeber (2004): Holocene slip rate of the North Anatolian Fault beneath the Sea of Marmara, Earth Planet. Sci. Lett., 227, 411-426.

Prawirodirdjo, L. and Y. Bock (2004): Instantaneous global plate motion model from 12 years of continuous GPS observations, J. Geophys. Res., 109, B08405, 1-15.

RAMDANI, F. (1998): Geodynamic implications of intermediate-depth earthquakes and volcanism in the intraplate Atlas mountains (Morocco), Phys. Earth Planet. Int., 108, 245-260.

RANERO, C.R., E. BANDA and P. BuHL (1997): Tre structure of the Canarian basin: accretion processes at slow spreading centers, J. Geophys. Res., 102, 10185-10201.

Rebai, S., H. Philip and A. Taboada (1992): Modern tectonic stress field in the Mediterranean region: evidence for variation in stress directions at different scale, Geophys. J. Int., 110, 106-141.

Reicherter, K.R. and G. Peters (2005): Neotectonic evolution of the Central Betic Cordilleras (Southern Spain), Tectonophysics, 405, 191-212.

Ribeiro, A., J. CABral, R. BAPtista and L. Matias (1996): Stress pattern in Portugal mainland and the adjacent Atlantic region, West Iberia, Tectonics, 15, 641-659.

RoBERTSON, A.H.F. (1998): Tectonic significance of the Eratosthenes Seamount: a continental fragment in the process of collision with a subduction zone in the eastern Mediterranean (Ocean Drilling Program Leg 160), Tectonophysics, 298, 63-82.

RoberTson, A.H.F. (2000): Mesozoic-Tertiary tectonic-sedimentary evolution of a south Tethyan oceanic basin and its margins in Southern Turkey, in Tectonics and Magmatism in Turkey and the Surrounding Area, edited by E. BozkurT, J.A. Winchester and J.D.A. PIPER, Geol. Soc. London Spec. Publ. 173, 97-138.

Rukieh, M., V.G. Trifonov, A.E. Dodonov, H. Minini, O. Ammar, T.P. Ivanova, T. ZaZA, A. Yusef, M. Al-Shara and Y. Jobaili (2005): Neotectonic map of Syria and some aspects of Late Cenozoic evolution of the northwestern boundary zone of the Arabian plate, J. Geodyn., 40 (2-3), 235-256.

Seber, D., M. Barazangi, B. Tadili, M. Ramdani, A. IbenBRAHIM and D. BEN SARI (1996): Three dimensional upper mantle structure beneath the intraplate Atlas and interplate Rif mountains of Morocco, J. Geophys. Res., 101, 3125-3138

SÉBrIER, M., A. GHAFIRI and J.-L. BlEs (1997): Paleoseismicity in France: fault trench studies in a region of moderate seismicity, J. Geodyn., 24, 207-217.

SÉbrier, M., L. Siame, E.M. Zouine, T. Winter, Y. Misse-
NARD and P. LETURMY (2006): Active tectonic in the Moroccan High Atlas, C.R. Geosci., 338, 65-79.

SElla, G.F., T.H. Dixon and A. MAO (2002): REVEL: a model for recent plate velocities from space geodesy, $J$. Geophys. Res., 107, ETG 11 1-32.

SEnGOR, A.M.C. and Y. YILmaZ (1981): Tethyan evolution of Turkey: a plate tectonic approach, Tectonophysics, 75, 181-241.

Serpelloni, E., M. Anzidei, P. Baldi, G. Casula and G. GALVANI (2005): Crustal velocity and strain-rate fields in Italy and surrounding regions: new results from the analysis of permanent and non-permanent GPS networks, Geophys. J. Int., 161, 861-880.

Suleiman, A.S., D.I. Doser and D.R. YARwood (1993): Source parameters of earthquakes along the coastal margin of West Africa and comparisons with earthquakes in the coastal margin settings, Tectonophysics, 222, 79-91.

Souriau, A. and H. Pauchet (1998): A new synthesis of the Pyrenean seismicity and its tectonic implications, Tectonophysics, 290, 221-244.

Souriau, A., M. Sylvander, A. Rigo, J.-F. Fels, J.-M. Douchain and C. Ponsolles (2001): Sismotectonique des Pyrénées: principales contraintes sismologiques, Bull. Soc. Géol. Fr. 172, 25-39.

Stich, D., C.J. Ammon and J. Morales (2003): Moment tensor solutions for small and moderate earthquakes in the Ibero-Maghreb region, J. Geophys. Res., 108, 2148, ESE 7, 1-19.

Stich, D., E. Serpelloni, F. Mancilla and J. Morales (2006): Kinematics of the Iberia-Maghreb plate contact from seismic moment tensors and GPS observations, Tectonophysics, 426, 295-317.

TeiXell, A., M.L. Arboleya and M. Julivert (2003): Tectonic shortening and topography in the Central High Atlas (Morocco), Tectonics, 22, 1051.

Teixell, A., P. Ayarza, H. Zeyen, M. Fernandez and M.L. ARbOLEYA (2005): Effects of mantle upwelling in a compressional setting: the Atlas Mountains of Morocco, Terra Nova, 17, 456-461.

Thiebot, E. and M.-A. Gutscher (2006): The Gibraltar Arc seismogenic zone, Part 1. Constraints on a shallow east dipping fault plane source for the 1755 Lisbon earthquake provided by seismic data, gravity and thermal modeling, Tectonophysics, 426,135-152.

UbANGOH, R.U., B. AtEBA, S.N. AyONGHE and G.E. EkOdECK (1997): Earthquake swarms of Mt. Cameroon, West Africa, J. Afr. Earth Sci., 24, 413-424.

Vidal, N., J. Alvarez MarRón and D. KlaEschen (2000): The structure of the Africa-Anatolia plate boundary in the Eastern Mediterranean, Tectonics, 19, 723-739.

Vilanova, S.P. and J.F.B.D. FonsecA (2004): Seismic hazard impact of the Lower Tagus Valley Fault Zone (SW Iberia), J. Seismology, 8, 331-345.

Viti, M., D. Albarello and E. Mantovani (2001): Classification of seismic strain estimates in the Mediterranean region from a 'bootstrap' approach, Geophys. J. Int., 146, 399-415.

Viti, M., J. De Luca, D. Babbucci, E. Mantovani, D. AlBARELLO and F. D'ONZA (2004): Driving mechanism of tectonic activity in the Northern Apennines: quantitative insights from numerical modeling, Tectonics, 23, TC4003, doi: 10.1029/2004TC001623.

Viti, M., E. Mantovani, D. BabBucci and C. TAMburelli 
(2006): Quaternary geodynamics and deformation pattern in the Southern Apennines: implications for seismic activity, Boll. Soc. Geol. Ital., 125, 273-291.

Wdowinski, S., Z. Ben-Avraham, R. Arvidsson and G. Ekstrom (2006): Seismotectonics of the Cyprian Arc, Geophys. J. Int., 164, 176-181.

Westaway, R. (1990): Present-day kinematics of the plate boundary zone between Africa and Europe, from the Azores to the Aegean, Earth Planet. Sci. Lett., 96, 393-406.

Willis, P., C. Boucher, H. Fagard and Z. Altamimi (2005): Applications géodésiques du système DORIS à l'Institut géographique national, C.R. Geosci., 337, 653-662.

Wysession, M.E., J. WiLson, L. BARTKò and R. SAKATA
(1995): Intraplate seismicity in the Atlantic Ocean Basin: a teleseismic catalog, Bull. Seismol. Soc. Am., 85, 755774.

YANG, Y. and L. MiAN (2002): Deformation of covergent plates: evidence from discrepancies between GPS velocities and rigid-plate motions, Geophys. Res. Lett., 29, doi: 10.1029/2001GL03391.

Yelles-Chaouche, A., A. Boudiaf, H. Djellit and R. BRACENE (2006): La tectonique active de la région nord-algérienne, C.R. Geosci., 338, 126-139.

(received January 15, 2007; accepted April 3, 2007) 